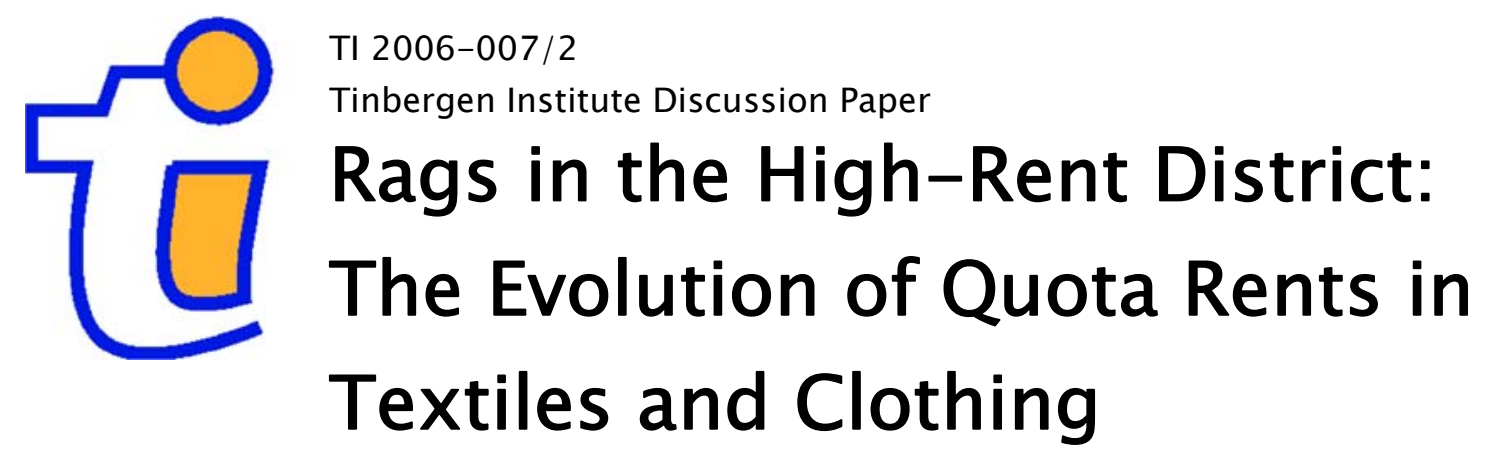

Joseph Francois ${ }^{1}$

Julia Woerz ${ }^{2}$

1 Erasmus University Rotterdam, and Tinbergen Institute;

${ }^{2}$ WIIW, Vienna. 


\section{Tinbergen Institute}

The Tinbergen Institute is the institute for economic research of the Erasmus Universiteit Rotterdam, Universiteit van Amsterdam, and Vrije Universiteit Amsterdam.

Tinbergen Institute Amsterdam

Roetersstraat 31

1018 WB Amsterdam

The Netherlands

Tel.: $\quad+31(0) 205513500$

Fax: $\quad+31(0) 205513555$

Tinbergen Institute Rotterdam

Burg. Oudlaan 50

3062 PA Rotterdam

The Netherlands

Tel.: $\quad+31(0) 104088900$

Fax: $\quad+31(0) 104089031$

Please send questions and/or remarks of nonscientific nature to driessen@tinbergen.nl.

Most TI discussion papers can be downloaded at http://www.tinbergen.nl. 


\title{
Rags in the High Rent District: the Evolution of Quota Rents in Textiles and Clothing *
}

\author{
Joseph Francois ${ }^{\mathrm{a}, \mathrm{b}}$ Julia Woerz ${ }^{\mathrm{b}, \mathrm{c}}$ \\ ${ }^{\mathrm{a}}$ CEPR (London) \\ ${ }^{\mathrm{b}}$ Tinbergen Institute (Rotterdam) \\ ${ }^{\mathrm{c}}$ WIIW (Vienna)
}

\begin{abstract}
We develop a mixed complementarity programming (MCP) based estimating framework for non-tariff barriers (NTBs) to examine the evolution of market access conditions in the textile and clothing sectors, working with a panel of bilateral trade data on textile and clothing trade, underlying bilateral tariffs, and the country-pair coverage of quotas under the WTO's Agreement on Textiles and Clothing (ATC). Our estimating framework takes advantage of the panel nature of trade data when calculating export tax equivalents while allowing for inequality constraints on the quota premium estimates. We also introduce Gaussian quadrature for estimating goodness of fit for regression-based NTB measures based on residual fitting.
\end{abstract}

Key words: NTB estimation, Gaussian Quadrature, import quotas, ATC, MFA JEL: F13, C15

\footnotetext{
* This research has benefitted from support from the EU RTN program on "Trade and Industrialization," DFID, IIIS(Dublin), and the World Bank.

Address for correspondence: J. Francois, Tinbergen Institute, Erasmus University Rotterdam, Burg Oudlaan 50-H8-18, 3000DR Netherlands.

email: francois@few.eur.nl, web: www.intereconomics.com/francois
} 


\title{
Rags in the High Rent District: the Evolution of Quota Rents in Textiles and Clothing
}

\begin{abstract}
We develop a mixed complementarity programming (MCP) based estimating framework for non-tariff barriers (NTBs) to examine the evolution of market access conditions in the textile and clothing sectors, working with a panel of bilateral trade data on textile and clothing trade, underlying bilateral tariffs, and the country-pair coverage of quotas under the WTO's Agreement on Textiles and Clothing (ATC). Our estimating framework takes advantage of the panel nature of trade data when calculating export tax equivalents while allowing for inequality constraints on the quota premium estimates. We also introduce Gaussian quadrature for estimating goodness of fit for regressionbased NTB measures based on residual fitting.
\end{abstract}

keywords: NTB estimation, Gaussian quadrature, quotas, ATC, MFA JEL: F13, C15 


\section{Introduction}

Quotas on textiles and clothing trade have been a basic feature of the modern trade landscape since the late 1950s. Given that these sectors are also the most important export category for many developing countries, like Bangladesh, these quotas have also been a painful thorn in the side of North-South trade relations. The Ministerial Declaration at Punta Del Este that launched the Uruguay Round stated that the "Negotiations in the area of textiles and clothing shall aim to formulate modalities that would permit the eventual integration of this sector into GATT (General Agreement on Tariffs and Trade) on the basis of strengthened GATT rules and disciplines." In plain English, this was a promise to developing countries that quotas on textiles and clothing were finally going to be eliminated. Indeed, this promise was critical to convincing developing countries to sign on at the creation of the then new World Trade Organization (WTO).

The Uruguay Round of GATT negotiations launched at Punta Del Este led to the Agreement on Textiles and Clothing (ATC) in 1995, the institutional shape given to the promise to end quotas in an orderly process. The ATC featured mechanisms for the gradual expansion of quotas and deliberate graduation of whole product categories from the regime. The agreement was flagged as a major showpiece in the Uruguay Round Agreements, and an important source of trade-based income gains linked to the introduction of the World Trade Organization (WTO). ${ }^{1}$

Technically, the quotas were indeed phased out in a ten year process ending in 2005. However, it is now clear the quota graduation did not work as advertised. Following a circus of ministerial panic and hurried negotiations in early 2005, the EU and US subsequently began re-imposing quotas in late 2005, focusing on adjustment costs related to China. The entire episode has raised important questions about the real effectiveness of staged liberalization programs in trade agreements that include administrative discretion, and about how much liberalization really took place under the WTOs Agreement on Textiles and Clothing (the ATC).

In this paper, we explore econometrically the evolution of market access conditions under the ATC in the textile and clothing sectors. Working with a panel of bilateral trade data on textile and clothing trade, underlying bilateral tariffs, and the bilateral pairing of quotas, we develop a nonlinear mixedcomplimentarity based estimation framework for non-tariff barriers (NTBs) that takes advantage of the panel-nature of the data when calculating tax equivalents. We also introduce the use of Gaussian quadrature for estimating

1 See Harrison, Rutherford, and Tarr (1995); Francois, McDonald, and Nordstrom (1995); Hertel et al (1995). 
goodness of fit for regression-based NTB measures based on residual fitting. In Section 2 we provide institutional background. In Section 3 we develop our estimating framework, while we discuss our estimates in Section 4 . We provide closing comments in Section 5.

\section{$2 \quad$ Background}

Like agriculture, the textiles and clothing sectors emerged in the early years of the GATT system as politically sensitive sectors. As such, they have been treated as a special case within the world trading system, with their own regulatory framework. While technically in violation of the GATT, the quotas were first institutionalized in the beginning of the 1960s with the Short Term Arrangements (STA) for international trade in cotton textiles. The STA aimed at an orderly opening of restricted markets to avoid (for importing countries) "detrimental market disruptions." The definition of "market disruption" adopted by the Contracting Parties in 1960 entailed the possibility of singling out imports of particular products from particular countries as the disrupting source. This opened the door for a series of bilaterally negotiated quota restrictions that became the rule in the following Long Term Arrangement (LTA) in 1962. The result has been a veritable alphabet soup of agreements governing trade in the textiles and clothing sectors. Details on the subsequent evolution of acronyms are provided in Table 1.

By the start of the 1970s, it had become apparent that the multiplicity of makeshift arrangements protecting the textile and clothing industries had to be replaced. Resulting negotiations led to the Multifibre Arrangement (MFA), which went into effect in 1974. Over time, its product coverage was extended from cotton to non-cotton textiles and clothing. The final MFA (known as MFA IV) was extended several times, leading in the end to the Agreement on Textiles and Clothing in 1995.

Like the preceding arrangements, the MFA provided rules for the imposition of quotas, either through bilateral agreements or unilateral actions, whenever actual or perceived surges of imports caused market disruption (Baughman et al 1997; Krishna and Tan, 1997). This included the threat of a surge. In the years leading up to the Uruguay Round Agreements, six developed participants actively applied quotas under the MFA - the EU, the U.S., Canada, Norway, Finland and Austria. These were applied almost exclusively on imports from developing countries. Sweden liberalized its textile and clothing regime in 1991 and actually managed to withdraw from the MFA. Sadly, it was forced to rejoin this regime when it joined the European Union. Two other developed country participants, Japan and Switzerland, did not impose MFA quotas, but instead restricted themselves to "signalling" a readiness to apply quotas by the act 
of being signatories to the MFA agreement, combined with (active) import surveillance. As shown by Winters (1994), import surveillance can, at least in concentrated industries, induce a fall in import levels as producers are trying to forestall explicit quotas. The restrictiveness of the applied MFA quotas, and subsequent ATC quotas, varied from product to product, and from supplier to supplier. Norway dropped the use of binding quotas with the shift from MFA to ATC.

By design, the ATC mapped a gradual phase-out of the quota restrictions carried over from the MFA regime. The integration of the products covered by the agreement was to be achieved in three stages under a ten-year transition period. The first stage called for the integration of products comprising not less than 16 percent of the total volume of each member's 1990 imports of the products listed in the annex to the Agreement. The second stage, beginning in year 4, required the integration of a further 17 percent. The third stage, beginning in year 8 , required that another 18 percent of imports be brought under normal GATT rules. Furthermore, each importing country was free to choose the products it would integrate at each stage, the only constraint being that they had to encompass products from each of the four groupings: tops and yarn, fabrics, made-up textile products, and clothing. Products that remained restricted during the transition period were to benefit from a progressively increasing quota. The previously applied MFA quota annual growth rates were to be scaled up by a factor of 16 percent in the first stage - for instance, from 3 percent to $(3 \times 1.16=) 3.48$ percent - an additional 25 percent in the second stage, and yet another 27 percent in the third stage. This turned a 3 percent initial annual growth rate to 5.52 percent in the third stage.

The stated intent of the ATC process was an orderly draw-down of restrictions, culminating in a smooth shift to quota-free trade in 2005. The reality has instead been a mix of panic among trade ministries, hurried and frantic negotiations, European trade embargoes on China, and the imposition of new quotas by both the US and the EU. In the next sections we quantify the impact of quotas under the ATC, and the evolution of their economic effects over the full ATC implementation period.

\section{Estimating Framework}

\subsection{Export Tax Equivalents}

The impact of quantitative restrictions on trade is reflected in per-unit economic rent generated by a binding quota. This is because a binding quota effectively limits the supply of the good in the importing market, resulting in 
a price markup and giving economic rents to those suppliers who have access to the market (i.e. who are able to export inside the quota). Since the quotas on textiles and clothing were administered as "voluntary" export restraints by the suppliers, often with the quotas distributed by auction, these rents can alternatively be seen as an implicit tax on exports. For these reasons, the effect of the quotas in the literature is generally expressed as an export tax equivalent or ETE.

One approach to estimating ETEs is based on comparisons of per unit auction or license prices to export unit values (Martin 2001, Andriamananjara et al. 2004). This method potentially underestimates the full impact of the quota since auction prices may be depressed if the importing agents have sufficient market power. Another, econometrically-based approach involves estimating the ETEs using residual based methods, either based on data for non-tariff barriers (Leamer 1990, Harrigan 1993) or based on trade and tariff data with the help of gravity-type models (Mayer 2003). We argue here that econometrically based estimates using the gravity model may themselves have a bias related to price elasticities that imply overestimation of tariff equivalents. As we follow this approach ourselves, we address this bias here.

In this section, we outline a set of techniques offering several improvements over current methods. First, we correct for bias in price elasticity estimates (a critical component in ETE calculations) by employing a 2-step estimation procedure. We do this because we expect (an expectation supported by the data) that trade elasticity estimates are biased downward when the sample includes quota-constrained trade. Second, we base our estimates on joint estimation across a broad sample of importers and exporters. This differs from the econometric literature in this area, which tends to focus on single importers. (See for example Evans and Harrigan 2005.) Our approach allows us to integrate the estimation process for the ETEs with the panel-based estimation of the underlying gravity model. Third, we also impose non-linear constraints on the quotas, allowing for the mixed-complimentarity aspect of the estimation problem. Finally, as we are working with estimates based on a large non-linear econometric system, we introduce Gaussian quadrature as a technique for assessing robustness of residual-based NTB estimates.

\subsection{Data}

To assess the evolution of textile and clothing quotas under the ATC, we work with trade and tariff data from the UNCTAD's COMTRADE and TRAINS databases and the WTO's database of applied tariffs. These data are available through the UNCTAD/ World Bank WITS (World Integrated Trade Solution) data system, and yield trade and applied tariff data spanning from 1996 to 
the present. For EU Members, we have had to combine common external tariff data from the WTO with individual Member import data from COMTRADE. Our trade and tariff data have been combined, in turn, with data on geographic distance taken from CEPII's recent compilation of various distance measures. (See Clair et al 2004.) In total, this yields a database with 47,500 observations on bilateral textile trade flows and 44,452 observations on bilateral clothing trade flows, including 27,442 observations on OECD textile imports and 26,071 observations on OECD clothing imports. Annually, the data range between roughly 2,200 and 7,000 bilateral flows per year and sector.

For the period covered by our sample, import quotas were maintained by the United States, Canada, and the (then 15) Members of the European Union. The U.S. import quotas (not all involving WTO Members) cover 46 exporters. The European Union import quotas (again not all involving WTO Members) cover 20 exporters. Canadian quotas covered 43 exporters at the launch of the ATC. In our sample, 18,412 of our textile data points involve imports by quota users, while 17,787 of our clothing datapoints involve imports by quota users.

\subsection{The Estimating Equation}

We start by specifying CES import demand functions. ${ }^{2}$ As we are working with data that reflect actual trade flows and actual prices, and for which therefore price indexes can be taken as given in each cross-section, this is consistent with either the Armington approach to modeling trade flows or Ethier/Krugman-type monopolistic competition based on CES demand for varieties produced by firms. When we turn to our data, we treat each year in our panel as representative of an equilibrium set of prices and transaction quantities.

Formally, starting from CES preferences, if we take any importing country $j$, demand for imports from source country $i$ can be written as follows:

$$
m_{i, j}=E_{j}\left(\frac{p_{i, j}}{\alpha_{i, j}}\right)^{-\sigma} P_{j}^{\sigma-1}
$$

\footnotetext{
${ }^{2}$ We can obtain a more general version of equation (1) in percent differences by manipulation of a standard import demand function. The CES representation is then a special case which we use as it maps directly to the standard representation of import demand in national and firm-level product differentiation models, and in the gravity model literature.
} 
where $m_{i, j}$ represents total imports by country $j$ from country $i, E_{j}$ is total expenditure on the product category, $p_{i, j}$ is the internal price index for goods imported from country $i, \alpha_{i, j}$ is the country weight, $P_{j}$ is the CES composite price index, and $\sigma$ is the absolute value of the Allen-elasticity of substitution. We will later assume that the weights $\alpha$ are similar across OECD importers, so that we can drop the second subscript.

We can in turn map world prices for goods, indexed across exporters $i$, to internal prices, indexed by importer $j$, as follows:

$$
P_{i, j}=P_{i}^{*}\left(1+\tau_{i, j}\right)\left(1+\omega_{i, j}\right) \gamma_{i, j}
$$

In equation (2), $P_{i}^{*}$ is the world price index for exports from country $i, \tau_{i, j}$ is the bilateral tariff applied to imports from country $i$ sold in country $j, \omega_{i, j}$ is the export tax equivalent of quantitative restraints, measuring the price impact of non-tariff barriers, and $\gamma_{i, j}$ measures transport costs following from goods moving between $i$ and $j$. Such costs may be a function of geographic distance, for example, as is well established in the gravity equation literature. (See for example Disidier and Head (2003) and Anderson and van Wijncoop (2003).)

To move from equations (1) and (2) to estimating equations, we first substitute equation (2) into equation (1), neglecting the quantitave constraints for a moment, and then take logs. This yields equation (3).

$$
\begin{aligned}
\log m_{i, j, t}= & \log E_{j}-\sigma \log P_{i} *-\sigma \log \left(1+\tau_{i, j}\right) \\
& -\sigma \log \gamma_{i, j}+\sigma \log \alpha_{i, j}+(\sigma-1) \log P_{j}
\end{aligned}
$$

We normalize the world fob price indexes to unity, such that imports net of trade and distance barriers map to quantities. We also assume similar country weights $\alpha$ in the cross-section, and specify transport costs $\gamma_{i, j}$ as a function of both geographic distance $D_{i, j}$ and a dummy for common borders $B_{i, j}$. Finally, we control for both the domestic internal price index $P$ and the set of import CES weights by time-varying importer and exporter dummies $X$ and $M$. In this, we follow Matayas (1997) in including fixed importer and exporter effects, though we depart from his specification in that we include time variations. ${ }^{3}$ For our panel of observations indexed over time $t$ we therefore have:

\footnotetext{
3 The us of country fixed effects in the recent literature on trade elasticities offers an elegant solution to a problem plaguing the earlier literature, linked to the estimation of unit values from trade value and quantity data. See ? and also Reinert and Shiells (1993) for discussion.
} 


$$
\begin{aligned}
\log m_{i, j, t}= & -\sigma \log (1+\tau)_{i, j, t}+\beta_{\text {border }} D_{i, j}+\beta_{\text {distnce }} \log \delta_{i, j} \\
& +\beta_{\text {time }} t+X_{i, t}+M_{j, t}+e_{i, j, t}
\end{aligned}
$$

When we introduce quotas, we take advantage of the fact that in observed trade data, expenditures will reflect the price impact of the quotas. This allows us to estimate the manifestation of these price effects through the export-tax equivalent of the quota. However, it is then important to recognize that a quota is either binding, or not binding. This means that the export tax equivalents of the quota $\omega_{i, j}$ will be either positive or zero, but will not be negative. We therefore impose inequality constraints on the ETEs of the quotas. Finally, as we are working with a panel, and we know that the ATC involved a staged process of quota expansion, we model the evolution of the ETEs over time using a truncated fourth-degree polynomial (meaning that its applicability in time $t$ depends on whether or not the inequality constraint is binding.) ${ }^{4}$ Putting all this together, we have:

$$
\begin{aligned}
\log m_{i, j}= & -\sigma \log (1+\tau)_{i, j, t}+\beta_{\text {border }} D_{i, j}+\beta_{\text {distnce }} \log \delta_{i, j} \\
& +\beta_{\text {time }} t+X_{i, t}+M_{j, t} \\
& -\sigma \log \left(1+\omega_{i, j, t}\right)+e_{i, j, t} \\
\log \left(1+\omega_{i, j, t}\right)= & \max \left\{\begin{array}{l}
a_{i, j}+a 1_{i, j} t+a 2_{i, j} t^{2}+a 3_{i, j} t^{3}+a 4_{i, j} t^{4} \\
0
\end{array}\right.
\end{aligned}
$$

The inequality constraint on the matrix of export tax equivalents is reflected in equation (6). Combined with the equality of the tariff and quota price elasticity $\sigma$ in equation (5), this puts us in the realm of non-linear estimation when we focus on the estimation of the quota price wedges $\omega$.

4 While not reported here, we have also estimated three different sets of quota price effects mapped to ATC stages 1,2 and 3 as indicated in Table 1. The fit of the regression is better when allowing for a more flexible, non-linear time trend over the whole period, though the results of both sets of estimation are qualitatively quite similar. Since many factors influencing the cost effects of the quotas (like for instance supplier capacity, tariffs, regional agreements, etc.) change annually and not with the different stages of the ATC, it seems to be reasonable to allow for greater flexibility in the estimation. Higher degree polynomials do not yield any real difference in the fit of the model to the trade data, based on a comparison of the resulting ETEs. 


\subsection{Two-Step Estimation and Gaussian Quadrature}

As shown in Section 4 below, trade elasticity estimates with a full sample (inclusive of quota-using importers) appear to be biased downward by the effect of quotas on trade for ATC importers. We therefore first estimate trade elasticities for a restricted sample (exclusive of ATC importers) using equation (4), and then impose the resulting estimates of coefficient means and standard deviations on the unrestricted (inclusive of quotas) sample using equations (6) and (5) to estimate the underlying ETEs for the full sample. This means that the first and second moments of our quota wedge estimates from the second stage estimation, being based on full-sample residuals, are a function of the corresponding moments for the trade elasticities that were estimated in the first stage.

We are interested not only in the ETEs themselves from equation (6), but also the robustness of the estimates with respect to underlying uncertainty in our estimates of key parameters in equation (5). One obvious solution is Monte Carlo simulations at the second stage. However, we are working with a system of over one hundred equations estimated over up to 47 thousand observations. In addition, as noted by Haber (1970), Monte Carlo simulations do not necessarily assure reasonable accuracy. As an alternative to Monte Carlo simulations, we instead use order three Gaussian quadrature to estimate the variance of our ETE estimates given that they are based on our estimates of the elasticities in equation (5). Recent research suggests that quadrature methods are preferable in several ways to Monte Carlo methods, in many cases being both less computationally demanding and at the same time more accurate (Schürer 2003).

Gaussian quadrature builds on treating numerical problems with stochastic exogenous variables (in this case our second-stage least-squares estimation building on uncertain coefficient estimates from the first stage least squares estimation) as numerical integration problems. This approach has now become relatively standard for assessing uncertainty in numerical solutions with respect to parameter uncertainty in large scale general equilibrium models. (See Arndt 1996, Plumb 2001, and Hertel et al 2004). However, as far as we are aware, it has not been applied in the context of NTB estimation based on gravity models of trade. We follow Arndt's characterization of Stroud (1957) solution for a third order approximation for the distribution of a set of random variables $v$ specified as function of stochastic variables $x$. Essentially, Stroud's solution defines a set of systematic draws in $x$ space sufficient to obtain estimates of the mean and variance of our variables $v$. Formally, for $n$ stochastic variables, we need only $k=2 n$ draws. Each draw starts by taking $g=n / 2$ pairs (taken to the greatest integer not exceeding $n / 2$ ) of systematic draws of stochastic variables $\gamma$ with mean zero and standard deviation one, denoted by 
$\gamma_{g, k}$. This yields a matrix $\Gamma$ of coefficient pairs $\gamma_{g}$, with number of rows equal to the number of stochastic variables $x$ (equation 7 ) and each column defining one quadrature in our parameter space (equation 8). In particular, denoting the vectors of the mean and standard deviation of variables $x$ by $\mu$ and $\sigma$ and assuming that $\sigma$ is diagonal, the desired quadrature (the set of systematic draws on $x$ ) is obtained as defined in equation (8).

$$
\begin{aligned}
\gamma_{g} & =\mid \begin{array}{l}
\sqrt{2} \cos \left(\frac{(2 g-1) k \pi}{n}\right) \\
\sqrt{2} \sin \left(\frac{(2 g-1) k \pi}{n}\right)
\end{array}(k=1,2, \ldots, 2 n) \quad(g=1,2, \ldots[n / 2]) \\
\Phi & =\mu+\Gamma \sigma
\end{aligned}
$$

Once we have the matrix of systematic draws on $x$, represented in equation (8) by $\Phi$, we then need to take this set $\Phi$ and solve the second-stage least squares estimation problem $2 n$ times, one with each set of draws on $x$ in $\Phi$. The resulting set of estimates for $v$ can then be used to directly estimate the mean and variance for $v$.

\section{Estimated ETEs: The Evolution of Quota Rents}

Tables 2 and 3 report OLS estimates for equation (4). The first column in both tables shows OLS results for the full sample, while the subsequent columns show OLS results for the sub-samples of non-OECD countries, OECD countries, and OECD countries excluding quota users. As quantity constraints, by definition, limit price-sensitivity, we should expect this to bias downward any estimate of price sensitivity, corresponding to the tariff elasticity in the Tables. Indeed, the pattern is one of significantly different, and higher, tariff elasticities when we exclude the countries that utilize quotas. In addition, the non-OECD countries exhibit a somewhat higher (though not significantly different) degree of price sensitivity than the non-quota OECD sample.

Because estimated price elasticities are otherwise biased downward, in estimating quota price effects through the system of equations (5) and (6) we start by imposing the estimated elasticities for the quota-free sub-sample. The estimation problem is then specified as a minimization problem with mixed-complimentarity constraints, where we impose the system of equations (6) and solve for the set of non-negative quota coefficients and importer and 
exporter dummies that minimize the sum of squared errors. ${ }^{5}$ The resulting estimated non-linear time trend of quota price effects gives us a broad sense of the evolution of the quota wedges over the stages of the ATC phase-out period. Gaussian quadrature is employed, based on the first and second moments of coefficients reported in column 4 of Tables 2 and 3 (with the CBERA coefficient estimates taken from column 3) to obtain the standard errors used to calculate $t$-ratios reported in the detailed annex tables. The full set of estimates by importer and exporter is reported in Annex Tables A-1 to A-6. Summary results are reported in Table 4 . The general pattern is one of significant estimates. Figure 1 shows the evolution of two of the most significant sets of ETEs (China and India) over time.

Table 4 reports information on the top five suppliers in textiles and clothing for the quota using importers, Canada, the USA, and the EU. Since China ranged among the top suppliers for all quota users in 2001, the evolution of the Chinese export tax equivalents as implied by the quotas can be read from the table. Canada is the quota user most compliant with the ATC among all three. The reduction in price wedges for China are especially impressive. Between 1996 and 2003 the export tax equivalent was reduced to zero from an estimated 6.3 per cent in textiles and as much as 43.7 per cent in clothing. Also against other suppliers, liberalization was substantial in Canada, even if some high barriers remained, mostly against minor suppliers (for instance Jamaica, Qatar, and Morocco). Further, as reported in Francois and Spinanger (2004), Canada - like the US - maintained a pattern of strong protection against suppliers of wool products. This results in high constraints among others for Eastern European suppliers on the North American market.

Turning to the US, export tax equivalents for China have gone up. Figure 1 shows that this has not been a linear trend, some reduction in ETEs took place until the end of the second stage of the ATC. Especially notable is the spike at the end of the ATC. It seems reasonable to blame this spike for contributing to the political problems caused by a surge in imports from China in early 2005 . These ended with reimposition of quotas in later 2005. The spike in U.S. quotas follows from the interaction of several factors. The first factor is the failure of quota growth to keep up with growth in potential trade. This is illustrated in Table 5. The table quantifies the strong expansion of the Chinese economy and thus the huge increase in export potential over the life of the ATC. This growth well surpassed quota growth rates. While the Chinese quotas on the US market increased by 33 percent in textiles and 41 per cent in clothing between 1994 and 2004 (See Table 5), Chinese GDP rose by 170 per cent over the same period. With a cumulative growth of 61 per cent, already the US

\footnotetext{
5 Our OLS results in Tables 2 and 3 were estimated in STATA, while the constrained least squares estimates of the quota premiums, including the application of Gaussian quadrature, were estimated with GAMS.
} 
GDP growth - as a proxy for the growth of import demand - surpassed the rate of quota expansion. Another factor was the ability to "borrow forward" on quotas. This meant that, for example, in late 2000 importers could borrow against 2001 quota limits. Obviously, by late 2004, there were no more quotas to borrow against, contributing to the late spike in US ETEs as the system, by construction, became increasingly restrictive.

Note that in 2001-2002, Vietnam graduated from Smoot-Hawley to MFN tariffs. Vietnam's trade is mapped to MFN tariffs in the WITS database, so that the estimates for the initial years in the Table (broadly mapping to ATC Stages 1 and 2) reflect Smoot-Hawley tariffs. The move to MFN rates is reflected in the dramatic drop in Vietnam's ETEs when moving into ATC Stage 3. Also note that, like Canada, the U.S. also had substantial protection against East European suppliers. This corresponded to a narrow set of wool-based products that were restricted by U.S. quotas. These quotas were not really an issue at the end of the Uruguay Round. In 1993, these countries were emerging from the fog of communism, and were not major players on world markets. Detailed examination of the quota and trade categories involved shows that the North American regimes are protecting domestic producers of wool fabrics, suits, and related items. This protection is quite high. Finally, several countries have been largely graduated toward a liberal trade regime. This includes many of the lower income Asian and African suppliers, as reflected by their absence from the Tables.

Overall, despite the surge in ETEs for the US shown in Figure 1, the observed backloading of trade liberalization vis-à-vis China should not be surprising and cannot be ascribed purely to non-compliance with the ATC. It was instead a consequence, in part, of the system. At the same time though, our results do suggest that the US in general did not implement the ATC according to plan. Between 1996 and 2004, protection against restricted suppliers went up for 15 exporters of textiles - with increases in tariff equivalents greater than ten per cent for Indonesia, China, Poland, Czech Republic, Hungary, Uruguay, and Slovakia. Only four suppliers - Cambodia, Macedonia, Brazil, and Pakistan faced decreasing export tax equivalents during the ATC. For clothing, three suppliers - Uruguay, Cambodia, and India - saw a fall in their ETEs, while nine suppliers faced increasing price distortions - Turkey, Bulgaria, China, Poland, Hungary, Slovakia, Romania, Czech Republic. The latter three faced increases of more than 100 per cent in ETEs. Finally, several countries with quotas had already moved towards a liberal trade regime, including many of the lower income Asian and African suppliers. This can be concluded from the absence of binding quotas under the ATC.

While there is a clear pattern towards liberalization for imports to the European Union, the degree of liberalization was more limited than in the Canadian case. Although trade with China grew more open, the degree of protection re- 
mained high at the end of the ATC. ${ }^{6}$ Figure 1 and Table 4 both show the fall in protection against China. However the tariff equivalents at the end of the ATC remained substantial. The removal of the quota system by 2005 thus implied a substantial surge in imports from China. Indeed, preliminary 2004 and 2005 figures showed tremendous increases in China's market share in the EU market, leading to a re-imposition of quotas by the middle of 2005. We estimate that textile and clothing imports from India were no longer restricted by the quotas in 2003. As such, the removal was not expected to show strong direct effects. Similar to the US market, imports from Vietnam were also restricted on the EU market at the end of the ATC. The estimated tariff equivalents were comparable to those for China. Thus, while the EU has moved towards more liberalization in textiles and clothing, protection remained high against China and Vietnam when the final stage of full liberalization in the ATC was reached. Thus, substantial restructuring among suppliers on the European textile and apparel market starting in 2005 should not be surprising.

The results reported in Table 4 and the annex tables are broadly in line with other, auction-based estimates in the literature. There are of course some differences between various estimates of protection due to differences in methods, quota price information, and aggregation problems. For example, the estimates by Martin (2004) and by Andriamananjara et al (2004) are both based on different sets of auction prices, while our estimates are based on a gravity-type trade model. In general, our estimates and both of theirs all report higher protection rates in the clothing industry than in textiles. This is reasonable, since textiles are one of the major inputs in clothing, thus blocking textile imports would hurt the domestic clothing industry, whose protection stands behind the quota system, in the importing countries. The results for protection against China are broadly in line between the three different studies. Protection against imports from China remained high until the very end of the quota system in 2005. As auction prices reflect the rents accruing to exporters, auction estimates also tend to be systematically lower than our estimates. This makes sense, as our estimates also capture rents accruing to importers.

\section{Summary and Discussion}

One of the lynchpins of the Uruguay Round Agreements was a plan to (finally) eliminate quotas on textiles and clothing. This plan, known as the Agreement

\footnotetext{
${ }^{6}$ Due to the reporting procedures for the EU to UNCTAD, we do not have full EU import data for 2004. (Neither do we have full Canadian data). Given that the ATC was implemented in stages with 2003 and 2004 both in the third stage, and that the EU and Canadian systems did not have borrow-forward provisions, we use 2003 estimates as upper bounds for 2004 in the discussion and in Figure 1.
} 
on Textiles and Clothing (the ATC), embodied commitments to a ten year, staged reduction in quotas. The process was meant to be orderly, systematic, and transparent. Yet the end of the ATC has seen surges in imports from China, panicked trade ministers, rushed meetings, and the reimposition of quotas on China by late 2005. In this paper, we have examined the evolution of textile and clothing quota rents under the ATC. A key message from the econometrics is that the problem of China's (PRC) textile and clothing sector integration was basically deferred rather than managed in stages. This was not solely a result of the ATC itself, but was certainly reinforced by insufficient pre-defined quota expansion rates during a period of outstandingly strong expansion of China's supply potential.

The patterns of protection explored in this paper have serious implications for the pattern of textile and clothing trade. Non-ATC suppliers, including U.S. FTA partner Mexico, EU customs union partner Turkey and the beneficiaries of EU trade preferences in Africa, can expect a dramatic erosion of competitive position. Recent quotas on China will slow this process, but most likely will not stop it. In the case of the United States, this implies a substantial shift of import demand for clothing toward China, Turkey, and India. In addition, sourcing of wool products can be expected to shift further out of North America. In the European Union, we should expect a large, but less so, shift of demand toward China as well. This is because the quota premium for China is less than the China premium for the United States. This will be accompanied by a further shift toward East Asian supplies, as the EU has higher East Asian premiums than the U.S. This means, of course, that in third markets, non-APC suppliers should pick up market share. This includes export markets like Australia, New Zealand, and Japan, in addition to the middle-income exporters.

In addition to backloading of liberalization, an additional area of concern related to the implementation of the ATC and associated Uruguay Round MFN-tariff reductions has been the scope for preference erosion, especially for the least developed African countries. Virtually all African countries have entered into contractual preference arrangements with the European Union, and obtain preferential treatment for certain exports in the United States and Japan, as well as in other developed country markets under GSP schemes. There has consequently been a concern that implementation of the market access results of the Uruguay Round would diminish rather than augment their trade and economic prospects. The scope for relative preference erosion under the ATC is different from that related to tariff preferences. (See Francois, Hoekman, and Manchin 2006). It follows instead from the fact that at the start of the ATC phase-out, some countries and regions faced much greater restrictions than others. The lower-income suppliers in India and elsewhere in South Asia, in particular, faced negative preferences, in the sense that they faced greater effective restrictions than suppliers from East Asia and elsewhere. 
The distributional effect of the MFA restrictions was thus to discriminate between developing countries, and against suppliers like India and Pakistan. Even where some developing countries were favoured by preferential access, this has been largely at the expense of other developing countries. The MFA and ATC have, in effect, been serving as a negative preference system, helping some developing country suppliers at the expense of others.

Rounding out the prospects for future trade and protection is the scope for contingent action against China. Specific contingent protection rules were included in China's protocol of WTO accession. These permit other WTO members to keep protectionist pressure up against China for 15 years. They cover special anti-surge clauses for textile and clothing products (4 years), general anti-surge clauses (12 years) and treatment of China as a "non-market economy" in antidumping cases (15 years). The ability of the US and the EU to press China on new quota limits should be viewed in the context of these contingent protection options. 


\section{References}

Anderson, J. and E. van Wincoop (2003). "Gravity with Gravitas: A Solution to the Border Puzzle" American Economic Review 93(1): 170-192.

Andriamananjara, S, J. Dean and D. Spinanger (2004). "Trading Apparel: Developing Countries in 2005. " mimeo, USITC and Kiel Insitut for World Economics.

Arndt, C. (1996). "An Introduction to Systematic Sensitivity Analysis via Gaussian Quadrature." Purdue University: GTAP technical paper no 2.

Baughman, L. R. Mirus, M. Morkre, and D. Spinanger (1997). "Of Tyre Cords, Ties, and Tents. " World Economy 4: 407-434.

Clair, G., G. Gaulier, T. Mayer, and S. Zignago (2004). "Notes on CEPIIs distances measures. " CEPII: Paris.

Disdier, A.C. and K. Head (2003). "Exaggerated Reports on the Death of Distance: Lessons from a Meta-Analysis. " mimeo, TEAM, Université de Paris I Panthéon Sorbonne.

Evans, C.L. and J. Harrigan (2005). "Tight Clothing: How the MFA Affects Asian Apparel Exports." in T. Ito and A. Rose (eds.), International Trade in East Asia: NBER-EASE vol 14 Chicago: University of Chicago Press: 367-386.

Francois, J.F. and D. Spinanger (2004). "Liberalizing Quotas on Textiles and Clothing: Has the ATC Actually Worked?" paper presented at the annual GTAP conference, Washington.

Francois, J.F. H.H. Glismann and D. Spinanger (2000). "The Cost of EU Trade Protection in Textiles and Clothing." Kiel Working Papers no. 997, August.

Francois, J.F. B. Hoekman. and M. Manchin (2005). "Preference Erosion and Multilateral Trade Liberalization." forthcoming in World Bank Economic Review.

Francois, J. B. McDonald and H. Nordstrom (1995). "Assessing the Uruguay Round." in W. Martin and L. Alan Winters, eds., The Uruguay Round and the Developing Economies, Cambridge University Press.

Haber, S. (1970) "Numerical evaluation of multiple integrals." SIAM Review 12: 481-525.

Harrigan, J. (1993). "OECD imports and trade barriers in 1983." Journal of International Economics 35 (1), 91-111.

Harrison, G.W., T.F. Rutherford and D.G. Tarr (1995). "Quantifiying the Uruguay Round." in W. Martin and L.A. Winters (eds.), The Uruguay Round and the Developing Economies (World Bank Discussion Paper 307. Washington, DC).

Hertel, T., D. Hummels, M. Ivanic, and R. Keeney (2004). "How Confident Can we Be in CGE-Based Assessments of Free Trade Agreements?" Purdue University: GTAP working paper no 26.

Hertel, T.W., W. Martin, K. Yanagishima and B. Dimaranan (1995). "Liberalizing Manufactures in a Changing World Economy." in W. Martin and L.A. Winters (eds.), The Uruguay Round and the Developing Economies 
(World Bank Discussion Paper 307. Washington, DC).

Krishna, K. And L.H. Tan (1997). "The Multifibre Arrangement in Practice: Challenging the Competitive Framework." in D. Robertson ed., East Asian Trade After the Uruguay Round, Cambridge.

Leamer, E. (1990). "Latin America as a target of trade barriers erected by the major developed countries in 1983." Journal of Development Economics 32, 337-368.

Martin, W. (2004). "Implications for Pakistan of abolishing the textile and clothing quotas." Report by The World Bank, April 30.

Matyas, L. (1997). "Proper Econometric Specification of the Gravity Model." The World Economy 20:363-368.

Mayer, T. and S. Zignago (2003). "Border Effects of the Atlantic Triangle." mimeo, paper presented at the RIN conference in Punta del Este, December.

Plumb, M. (2001). "An Integrated Microsimulation and Applied General Equilibrium Approach to Modeling Fiscal Reform. " presented at the Econometric Society 2001 meetings.

Reinert, K. and C.R. Shiells (1993). "Armington Models and Terms-of-Trade Effects: Some Econometric Evidence for North America." The Canadian Journal of Economics 26(2): pp. 299-316.

Schürer, R. (2003). "A Comparison Between (Quasi-) Monte Carlo and Cubature Rule Based Methods for Solving High-dimensional Integration Problems." Mathematics and Computers in Simulation 62(3): 509-517.

Shiells, C.R. (1991). "Errors in Import-Demand Estimates Based Upon UnitValue Indexes." The Review of Economics and Statistics 73(2):378-382.

Stroud, A.H. (1957). "Remarks on the Disposition of Points in Numerical Integration Formulas." Ma 4: 407-434.

Winters, L.A. (1994). "The EC and Protection: the Political Economy. "European Economic Review April (38:3-4): 596-603. 
ETEs for textiles

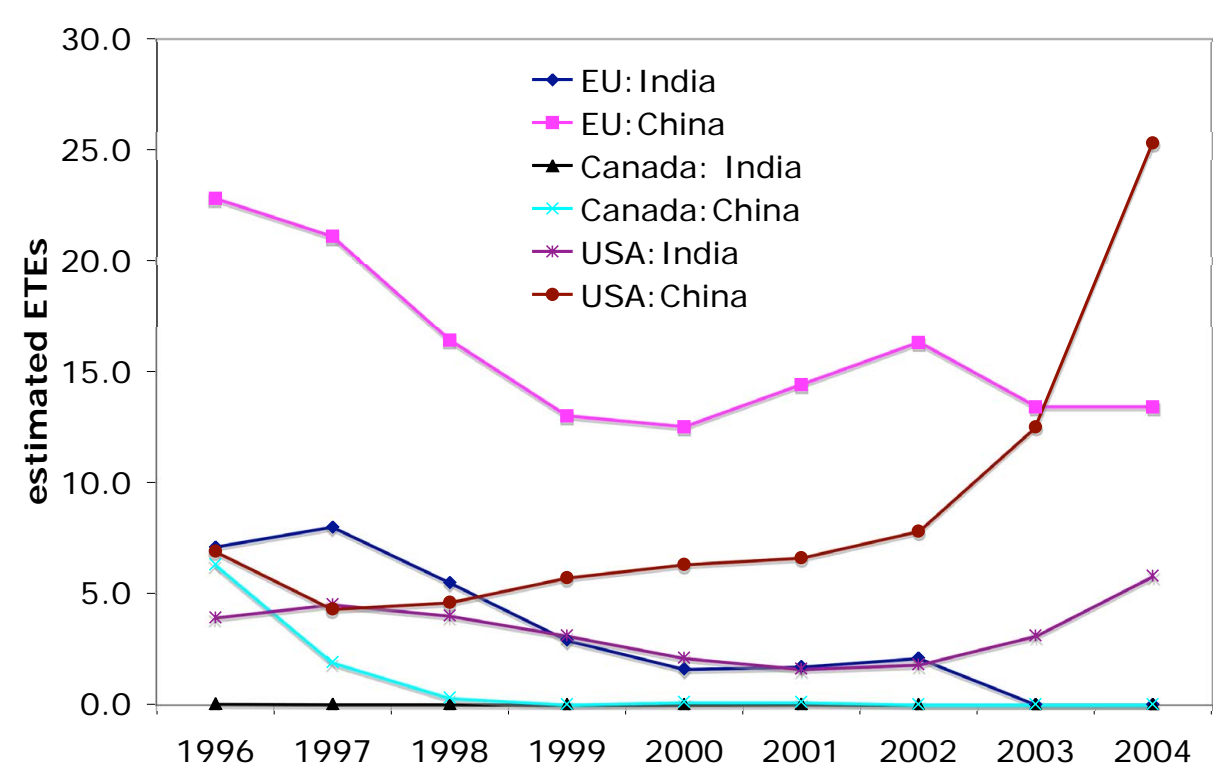

ETEs for clothing

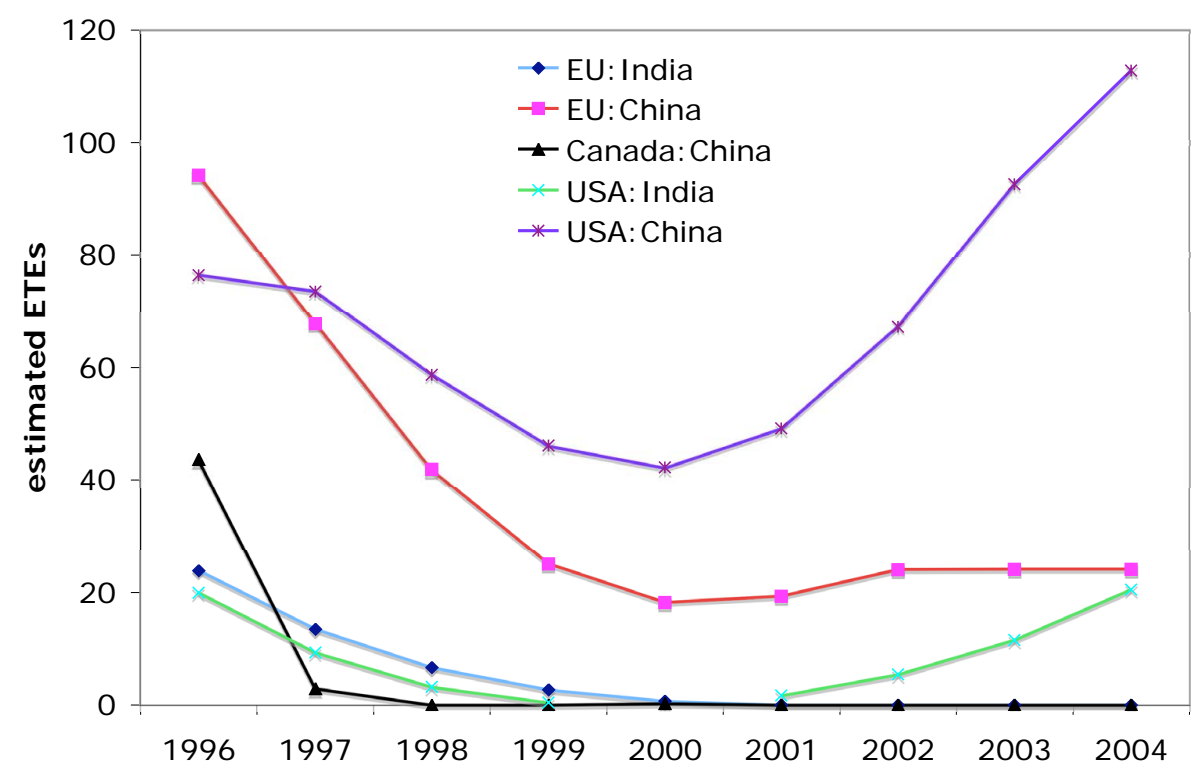

Fig. 1. The Evolution of Textile and Clothing ETEs for China and India 
Table 1

A Parade of Acronyms: the evolution of quotas

\begin{tabular}{|c|c|}
\hline year & overview of events \\
\hline $1955-57$ & $\begin{array}{l}\text { U.S.-Japan dispute leads to a } 5 \text { year agreement limiting } \\
\text { textile exports }\end{array}$ \\
\hline 1958 & $\begin{array}{l}\text { United Kingdom imposes "voluntary" limitation on cotton } \\
\text { T\&C products with Hong Kong, by threatening to otherwise } \\
\text { impose quotas at levels lower than prevailing volumes. }\end{array}$ \\
\hline 1959 & $\begin{array}{l}\text { United Kingdom signs restraint agreements with India and } \\
\text { Pakistan. }\end{array}$ \\
\hline 1960 & $\begin{array}{l}\text { GATT Contracting Parties recognize the problem of "market } \\
\text { disruption" to serve as an "excuse" for establishing future NTBs. }\end{array}$ \\
\hline 1961 & STA: The Short Term Arrangement (STA) is agreed. \\
\hline 1962 & $\begin{array}{l}\text { LTA1: The Long Term Arrangement (LTA) is agreed, to } \\
\text { commence October } 1,1962 \text {, and last for five years. }\end{array}$ \\
\hline $1963-65$ & U.S. tries and fails to establish agreement on trade in wool products \\
\hline 1966 & $\begin{array}{l}\text { The United Kingdom implements a global quota scheme in violation } \\
\text { of the LTA. The LTA provides only for product-specific restraints. }\end{array}$ \\
\hline 1967 & LTA2:Agreement is reached to extend the LTA for three years. \\
\hline $1969-71$ & $\begin{array}{l}\text { United States negotiates VERs with Asian suppliers on wool and } \\
\text { man-made fibers. }\end{array}$ \\
\hline 1970 & $\begin{array}{l}\text { LTA3:Agreement is reached to extend the LTA for three years. } \\
\text { It was later extended three months more, to fill the gap until the } \\
\text { MFA came into effect. }\end{array}$ \\
\hline 1973 & $\begin{array}{l}\text { MFA I:The MFA is agreed, to commence January } 1,1974, \\
\text { and to last for four years. }\end{array}$ \\
\hline 1977 & $\begin{array}{l}\text { The European Economic Community and the United States } \\
\text { negotiates bilateral agreements with developing countries } \\
\text { prior to agreeing to extension of the MFA. }\end{array}$ \\
\hline 1977 & MFA II:The MFA is extended for four years. \\
\hline 1981 & $\begin{array}{l}\text { MFA III:The MFA is renewed for five years. The USA, under } \\
\text { pressure from increased imports resulting from dollar appreciation, } \\
\text { negotiates tough quotas. }\end{array}$ \\
\hline 1986 & $\begin{array}{l}\text { MFA IV:The MFA is extended for } 5 \text { years, to conclude with the } \\
\text { expected end of the Uruguay Round. }\end{array}$ \\
\hline 1991 & $\begin{array}{l}\text { MFA IV+:The MFA is extended pending outcome of the } \\
\text { Uruguay Round negotiations. }\end{array}$ \\
\hline 1993 & $\begin{array}{l}\text { The Uruguay Round (UR) draft final act provides for a 10-year } \\
\text { phase-out of all MFA and other quotas on textiles in ATC. MFA } \\
\text { extends until UR comes into force. ATC allows credit for } \\
\text { liberalization in products that are not actually restricted. }\end{array}$ \\
\hline 1995 & ATC1:1st ATC tranche liberalized 16\% of 1990 imports. \\
\hline 1998 & ATC2:2nd ATC tranche liberalized $17 \%$ of 1990 imports. \\
\hline 2001 & ATC3:3rd ATC tranche liberalized $18 \%$ of 1990 imports. \\
\hline 2005 & $\begin{array}{l}\text { ATC4:4th ATC tranche liberalized } 49 \% \text { of } 1990 \text { imports. } \\
\text { Déjà } \boldsymbol{v} \boldsymbol{u} \text { all over again: U.S. and EU re-impose quotas on China. }\end{array}$ \\
\hline
\end{tabular}

Source: Based on an update of Francois, Glismann, and Spinanger (2000). 
Table 2

Textile Regressions

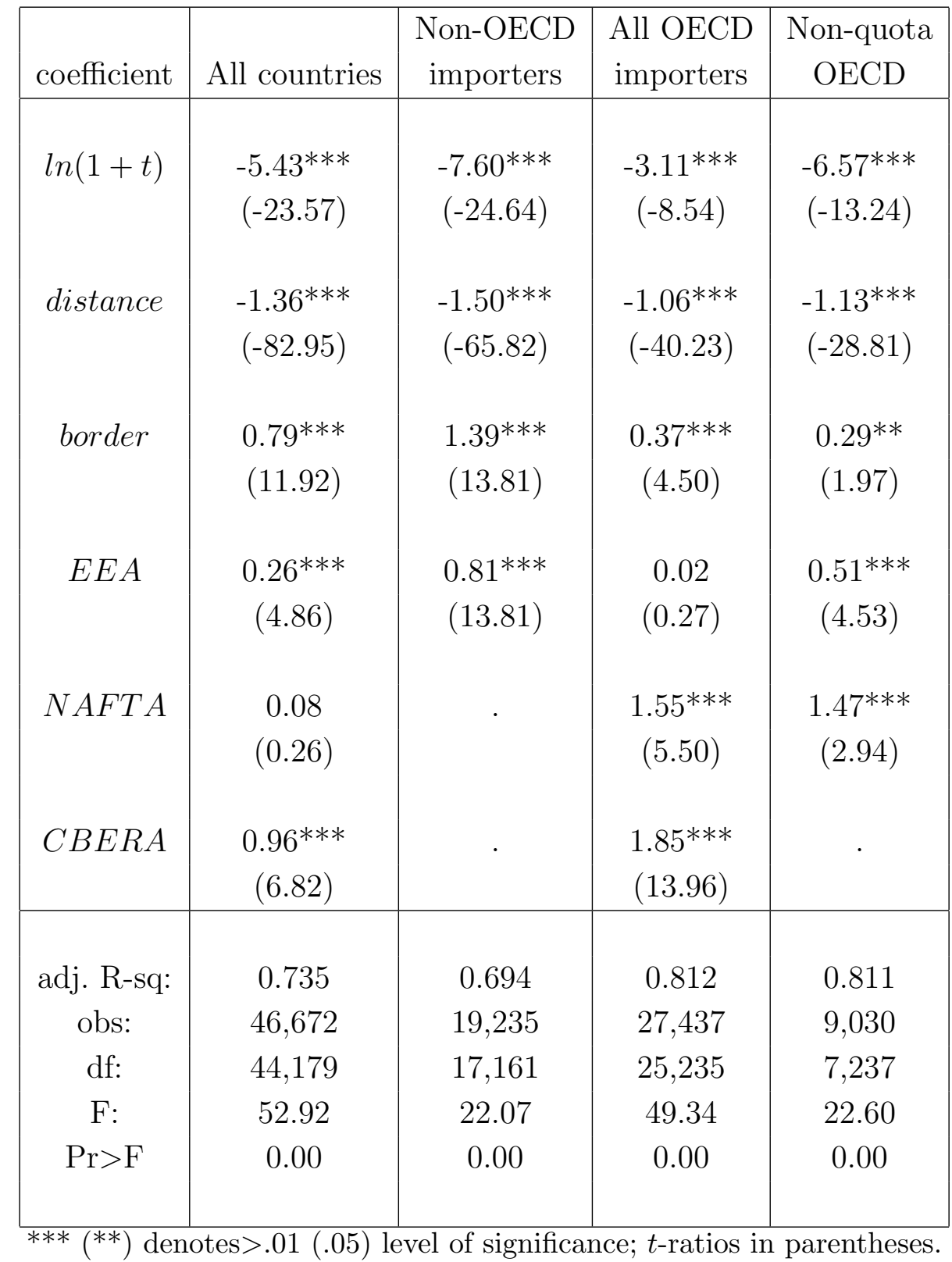


Table 3

Clothing Regressions

\begin{tabular}{|c|c|c|c|c|}
\hline coefficient & All countries & $\begin{array}{l}\text { Non-OECD } \\
\text { importers }\end{array}$ & $\begin{array}{l}\text { All OECD } \\
\text { importers }\end{array}$ & $\begin{array}{c}\text { Non-quota } \\
\text { OECD }\end{array}$ \\
\hline $\ln (1+t)$ & $\begin{array}{c}-0.08 \\
(-0.28)\end{array}$ & $\begin{array}{c}-2.26^{* * *} \\
(-4.65)\end{array}$ & $\begin{array}{c}0.02 \\
(0.04)\end{array}$ & $\begin{array}{c}-2.09^{* * *} \\
(-3.98)\end{array}$ \\
\hline distance & $\begin{array}{c}-1.39 * * * \\
(-81.59)\end{array}$ & $\begin{array}{c}-1.42^{* * *} \\
(-58.07)\end{array}$ & $\begin{array}{c}-1.08 * * * \\
(-40.44)\end{array}$ & $\begin{array}{c}-1.24^{* * *} \\
(-32.38)\end{array}$ \\
\hline border & $\begin{array}{c}0.83^{* * *} \\
(12.25)\end{array}$ & $\begin{array}{c}1.35^{* * *} \\
(12.72)\end{array}$ & $\begin{array}{c}0.51^{* * *} \\
(5.98)\end{array}$ & $\begin{array}{c}0.56^{* * *} \\
(3.62)\end{array}$ \\
\hline$E E A$ & $\begin{array}{c}0.36^{* * *} \\
(6.37)\end{array}$ & $\begin{array}{c}0.72^{* * *} \\
(7.35)\end{array}$ & $\begin{array}{c}0.42^{* * *} \\
(5.55)\end{array}$ & $\begin{array}{c}0.10 \\
(-0.92)\end{array}$ \\
\hline$N A F T A$ & $\begin{array}{c}0.31 \\
(1-02)\end{array}$ & . & $\begin{array}{c}1.34^{* * *} \\
(4.71)\end{array}$ & $\begin{array}{c}1.35^{* * *} \\
(2.78)\end{array}$ \\
\hline$C B E R A$ & $\begin{array}{c}0.14^{* * *} \\
(9.23)\end{array}$ & . & $\begin{array}{c}2.09^{* * *} \\
(15.57)\end{array}$ & . \\
\hline $\begin{array}{c}\text { adj. R-sq: } \\
\text { obs: } \\
\text { df: } \\
\text { F: } \\
\operatorname{Pr}>\text { F }\end{array}$ & $\begin{array}{c}0.745 \\
43,273 \\
40,811 \\
52.25 \\
0.00\end{array}$ & $\begin{array}{c}0.672 \\
17,202 \\
15,251 \\
15.83 \\
0.00\end{array}$ & $\begin{array}{c}0.800 \\
26,071 \\
23,884 \\
48.47 \\
0.00\end{array}$ & $\begin{array}{c}0.797 \\
8,284 \\
6,578 \\
20.10 \\
0.00\end{array}$ \\
\hline
\end{tabular}


Table 4

Top 5 Import Suppliers

\begin{tabular}{|c|c|c|c|c|}
\hline & \multirow{2}{*}{$\begin{array}{c}2001 \\
\text { import } \\
\text { share }\end{array}$} & \multirow{2}{*}{$\begin{array}{l}2001 \\
\text { tariff }\end{array}$} & \multicolumn{2}{|c|}{ ETEs } \\
\hline & & & 1996 & 2003 \\
\hline & \multicolumn{4}{|c|}{ EU15: textiles } \\
\hline Turkey & 14.0 & 0.0 & & \\
\hline China & 9.1 & 8.2 & $22.8^{* * *}$ & $13.4^{* * *}$ \\
\hline India & 8.1 & 7.5 & $7.1^{* * *}$ & \\
\hline United States & 4.7 & 6.4 & & \\
\hline Pakistan & 4.6 & 0.0 & $15.1^{* * *}$ & 0.01 \\
\hline \multirow[t]{2}{*}{ ALL } & 100.0 & 1.8 & 1.8 & 0.7 \\
\hline & \multicolumn{4}{|c|}{ EU15: clothing } \\
\hline China & 17.1 & 10.6 & $94.2^{* * *}$ & $24.1^{* * *}$ \\
\hline Turkey & 8.5 & 0.0 & & \\
\hline Romania & 6.6 & 0.0 & & \\
\hline Tunisia & 6.2 & 0.0 & & \\
\hline India & 5.8 & 8.5 & $23.9^{* * *}$ & \\
\hline \multirow[t]{2}{*}{ ALL } & 100.0 & 3.2 & 15.1 & 3.7 \\
\hline & \multicolumn{4}{|c|}{$U S A:$ textiles } \\
\hline Mexico & 12.7 & 0.1 & & \\
\hline European Union & 10.9 & 8.5 & & \\
\hline China & 10.2 & 7.4 & $6.9^{* * *}$ & $25.3^{* * *}$ \\
\hline Canada & 7.7 & 0.0 & & \\
\hline Pakistan & 5.4 & 9.0 & $5.5^{* * *}$ & $2.9^{* * *}$ \\
\hline \multirow[t]{2}{*}{ ALL } & 100.0 & 7.9 & 4.0 & 3.6 \\
\hline & \multicolumn{4}{|c|}{$U S A:$ clothing } \\
\hline China & 13.3 & 9.8 & $76.4^{* * *}$ & $112.8^{* * *}$ \\
\hline Mexico & 12.1 & 0.1 & & \\
\hline Hong Kong & 6.9 & 11.5 & & \\
\hline European Union & 4.5 & 10.1 & & \\
\hline Indonesia & 4.3 & 12.7 & & \\
\hline \multirow[t]{2}{*}{ ALL } & 100.0 & 9.9 & 11.4 & 16.9 \\
\hline & \multicolumn{4}{|c|}{ Canada: textiles } \\
\hline United States & 54.2 & 0.0 & & \\
\hline European Union & 8.7 & 9.4 & & \\
\hline China & 7.4 & 13.5 & $6.3^{* * *}$ & \\
\hline Korea & 4.4 & 10.3 & & \\
\hline India & 3.6 & 10.9 & 0.0 & \\
\hline \multirow[t]{2}{*}{ ALL } & 100.0 & 5.2 & 0.5 & 0.0 \\
\hline & \multicolumn{4}{|c|}{ Canada: clothing } \\
\hline China & 27.4 & 15.6 & $43.7^{* * *}$ & \\
\hline United States & 12.0 & 0.0 & & \\
\hline European Union & 8.0 & 16.3 & & \\
\hline India & 7.8 & 17.7 & & \\
\hline Hong Kong & 6.4 & 17.9 & & \\
\hline ALL & 100.0 & 14.5 & 13.1 & 0.1 \\
\hline
\end{tabular}


Table 5

Cumulative Growth in percent: 1994-2004

\begin{tabular}{|l|r|r|r|r|r|r|}
\hline \multirow{2}{*}{} & \multicolumn{3}{|c|}{ quota growth } & \multicolumn{2}{c|}{ GDP growth } \\
\cline { 2 - 5 } & \multicolumn{2}{|c|}{ textiles } & \multicolumn{2}{c|}{ clothing } & & \\
\cline { 2 - 5 } & US & EU & US & EU & per-capita & in total \\
\hline importer & & & & & & 66 \\
United States & & & & & 49 & 61 \\
European Union & & & & & 55 & \\
exporter & & & & & & \\
Bangladesh & 168 & & & & & 53 \\
China & 33 & 50 & 41 & 38 & 151 & 171 \\
Hong Kong & 37 & 16 & 17 & 22 & 1 & 16 \\
India & 141 & 50 & 116 & 79 & 57 & 84 \\
Indonesia & 134 & 83 & 133 & 117 & 19 & 35 \\
South Korea & 37 & 70 & 12 & 38 & 34 & 44 \\
Pakistan & 139 & 79 & 150 & 119 & 30 & 63 \\
Sri Lanka & 134 & 204 & 132 & 204 & 43 & 56 \\
Philippines & 134 & 112 & 119 & 112 & 1 & 21 \\
Thailand & 127 & 116 & 123 & 116 & -10 & -1 \\
\hline Source: Martin (2004) & Eurostat, IFS, and own calculations.
\end{tabular}


Table A-1

Canada: non-linear least squares estimates of ETEs for textiles

\begin{tabular}{|c|c|c|c|c|c|c|c|c|}
\hline \multirow{2}{*}{$\begin{array}{l}\text { supplier } \\
\text { Arab. Emirates }\end{array}$} & 1996 & 1997 & 1998 & 1999 & 2000 & 2001 & 2002 & 2003 \\
\hline & $\begin{array}{c}29.5 \\
(10.53)\end{array}$ & $\begin{array}{c}15.7 \\
(11.92)\end{array}$ & $\begin{array}{c}9.5 \\
(11.04)\end{array}$ & $\begin{array}{c}5.8 \\
(9.53)\end{array}$ & $\begin{array}{c}2.6 \\
(8.59)\end{array}$ & & & $\begin{array}{c}6.8 \\
(7.35)\end{array}$ \\
\hline Bangladesh & $\begin{array}{c}2.2 \\
(3.95)\end{array}$ & $\begin{array}{c}0.5 \\
(3.96)\end{array}$ & & & $\begin{array}{c}0.1 \\
(2.87)\end{array}$ & $\begin{array}{c}0.1 \\
(1.76)\end{array}$ & & $\begin{array}{c}0.1 \\
(0.53)\end{array}$ \\
\hline Bulgaria & & & & $\begin{array}{c}0.5 \\
(1.6)\end{array}$ & $\begin{array}{c}1.4 \\
(1.6)\end{array}$ & $\begin{array}{c}2.3 \\
(1.6)\end{array}$ & $\begin{array}{c}2.3 \\
(1.6)\end{array}$ & \\
\hline China & $\begin{array}{c}6.3 \\
(7.71)\end{array}$ & $\begin{array}{c}1.9 \\
(6.07)\end{array}$ & $\begin{array}{c}0.3 \\
(2.89)\end{array}$ & & $\begin{array}{c}0.1 \\
(2.56)\end{array}$ & $\begin{array}{c}0.1 \\
(3.9)\end{array}$ & & \\
\hline Costa Rica & $\begin{array}{c}2.5 \\
(1.35)\end{array}$ & $\begin{array}{c}2.6 \\
(2.16)\end{array}$ & $\begin{array}{c}0.8 \\
(0.66)\end{array}$ & $\begin{array}{c}1.6 \\
(1.14)\end{array}$ & $\begin{array}{c}6.6 \\
(3.54)\end{array}$ & $\begin{array}{c}13.9 \\
(5.88)\end{array}$ & $\begin{array}{c}17.7 \\
(6.79)\end{array}$ & $\begin{array}{c}8.0 \\
(3.94)\end{array}$ \\
\hline Dom. Rep. & $\begin{array}{c}0.3 \\
(0.44)\end{array}$ & $\begin{array}{c}0.1 \\
(0.44)\end{array}$ & $\begin{array}{c}0.03 \\
(0.44)\end{array}$ & & & $\begin{array}{c}0.01 \\
(0.44)\end{array}$ & & \\
\hline Hungary & $\begin{array}{c}6.7 \\
(3.84)\end{array}$ & $\begin{array}{c}0.7 \\
(2.72)\end{array}$ & 0.0 & $\begin{array}{c}1.0 \\
(1.29)\end{array}$ & $\begin{array}{c}1.7 \\
(1.45)\end{array}$ & $\begin{array}{c}1.3 \\
(1.47)\end{array}$ & $\begin{array}{c}0.1 \\
(0.56)\end{array}$ & \\
\hline India & $\begin{array}{c}0.04 \\
(0.46)\end{array}$ & $\begin{array}{c}0.02 \\
(0.46)\end{array}$ & $\begin{array}{c}0.01 \\
(0.46)\end{array}$ & & & $\begin{array}{c}0.01 \\
(0.46)\end{array}$ & & \\
\hline Jamaica & $\begin{array}{l}23.0 \\
(7.6)\end{array}$ & $\begin{array}{c}8.3 \\
(3.65)\end{array}$ & $\begin{array}{c}15.4 \\
(5.66)\end{array}$ & $\begin{array}{c}30.1 \\
(7.65)\end{array}$ & $\begin{array}{c}42.6 \\
(8.31)\end{array}$ & $\begin{array}{l}47.2 \\
(8.5)\end{array}$ & $\begin{array}{c}45.7 \\
(8.45)\end{array}$ & $\begin{array}{c}48.3 \\
(8.22)\end{array}$ \\
\hline Cambodia & $\begin{array}{c}28.8 \\
(10.05)\end{array}$ & $\begin{array}{c}16.8 \\
(11.24)\end{array}$ & $\begin{array}{c}15.9 \\
(10.24)\end{array}$ & $\begin{array}{c}16.4 \\
(9.31)\end{array}$ & $\begin{array}{c}13.4 \\
(8.96)\end{array}$ & $\begin{array}{c}6.7 \\
(8.99)\end{array}$ & & \\
\hline Lao PDR & $\begin{array}{c}21.4 \\
(10.31)\end{array}$ & $\begin{array}{c}1.1 \\
(2.9)\end{array}$ & $\begin{array}{c}0.1 \\
(0.58)\end{array}$ & $\begin{array}{c}4.8 \\
(8.95)\end{array}$ & $\begin{array}{c}7.9 \\
(8.52)\end{array}$ & $\begin{array}{c}6.7 \\
(6.85)\end{array}$ & $\begin{array}{c}3.6 \\
(6.42)\end{array}$ & $\begin{array}{c}6.1 \\
(10.41)\end{array}$ \\
\hline Lebanon & $\begin{array}{c}52.8 \\
(11.66)\end{array}$ & $\begin{array}{c}10.6 \\
(13.62)\end{array}$ & & & $\begin{array}{c}2.0 \\
(14.17)\end{array}$ & $\begin{array}{c}2.0 \\
(14.17)\end{array}$ & & \\
\hline Sri Lanka & $\begin{array}{c}2.7 \\
(2.92)\end{array}$ & $\begin{array}{c}1.0 \\
(2.94)\end{array}$ & $\begin{array}{c}0.2 \\
(2.95)\end{array}$ & & & $\begin{array}{c}0.02 \\
(2.95)\end{array}$ & & \\
\hline Lesotho & $\begin{array}{c}60.9 \\
(10.6)\end{array}$ & $\begin{array}{c}19.5 \\
(9.18)\end{array}$ & $\begin{array}{c}4.7 \\
(6.06)\end{array}$ & $\begin{array}{c}0.4 \\
(1.73)\end{array}$ & & $\begin{array}{c}0.3 \\
(9.65)\end{array}$ & & \\
\hline Morocco & $\begin{array}{c}7.4 \\
(7.69)\end{array}$ & $\begin{array}{c}1.3 \\
(2.9)\end{array}$ & $\begin{array}{c}2.6 \\
(5.42)\end{array}$ & $\begin{array}{c}7.1 \\
(9.13)\end{array}$ & $\begin{array}{c}12.0 \\
(10.39)\end{array}$ & $\begin{array}{c}15.3 \\
(10.81)\end{array}$ & $\begin{array}{c}16.6 \\
(10.61)\end{array}$ & $\begin{array}{c}16.8 \\
(9.41)\end{array}$ \\
\hline Malaysia & $\begin{array}{c}7.5 \\
(6.28)\end{array}$ & $\begin{array}{c}2.6 \\
(6.43)\end{array}$ & $\begin{array}{c}0.6 \\
(6.49)\end{array}$ & & & $\begin{array}{c}0.1 \\
(6.51)\end{array}$ & & \\
\hline Oman & $\begin{array}{c}30.8 \\
(8.15)\end{array}$ & $\begin{array}{c}6.6 \\
(9.01)\end{array}$ & & & $\begin{array}{c}1.3 \\
(9.24)\end{array}$ & $\begin{array}{c}1.3 \\
(9.24)\end{array}$ & & \\
\hline Pakistan & $\begin{array}{c}0.8 \\
(1.7)\end{array}$ & $\begin{array}{c}0.3 \\
(1.7)\end{array}$ & $\begin{array}{c}0.1 \\
(1.71)\end{array}$ & & & $\begin{array}{c}0.01 \\
(1.7)\end{array}$ & & \\
\hline Korea, PR & & & & $\begin{array}{l}206.3 \\
(7.78)\end{array}$ & $\begin{array}{c}114.8 \\
(8.59)\end{array}$ & $\begin{array}{l}123.4 \\
(8.32)\end{array}$ & $\begin{array}{l}86.7 \\
(9.6)\end{array}$ & $\begin{array}{l}112.7 \\
(8.95)\end{array}$ \\
\hline Quatar & & $\begin{array}{c}4.9 \\
(4.77)\end{array}$ & $\begin{array}{c}36.4 \\
(12.18)\end{array}$ & $\begin{array}{l}131.5 \\
(8.68)\end{array}$ & $\begin{array}{l}197.0 \\
(7.49)\end{array}$ & $\begin{array}{l}139.8 \\
(8.08)\end{array}$ & $\begin{array}{c}47.3 \\
(10.53)\end{array}$ & $\begin{array}{c}20.0 \\
(15.7)\end{array}$ \\
\hline Romania & & & & $\begin{array}{c}0.1 \\
(0.96)\end{array}$ & $\begin{array}{c}0.3 \\
(1.19)\end{array}$ & $\begin{array}{c}0.7 \\
(1.58)\end{array}$ & $\begin{array}{c}1.5 \\
(2.34)\end{array}$ & $\begin{array}{c}2.5 \\
(3.74)\end{array}$ \\
\hline Russia & $\begin{array}{c}2.2 \\
(3.16)\end{array}$ & $\begin{array}{c}1.0 \\
(3.18)\end{array}$ & $\begin{array}{c}0.3 \\
(3.19)\end{array}$ & $\begin{array}{c}0.1 \\
(3.19)\end{array}$ & & & & \\
\hline Singapore & $\begin{array}{c}3.6 \\
(4.19)\end{array}$ & $\begin{array}{c}1.4 \\
(3.21)\end{array}$ & $\begin{array}{l}0.4 \\
(2)\end{array}$ & $\begin{array}{c}0.0 \\
(0.7)\end{array}$ & & (1.58) & & \\
\hline Slovakia & & & $\begin{array}{c}1.6 \\
(2.6)\end{array}$ & $\begin{array}{c}3.2 \\
(2.39)\end{array}$ & $\begin{array}{c}3.9 \\
(2.14)\end{array}$ & $\begin{array}{c}3.2 \\
(1.83)\end{array}$ & $\begin{array}{c}1.6 \\
(1.41)\end{array}$ & \\
\hline Swaziland & & $\begin{array}{c}27.6 \\
(9.38)\end{array}$ & $\begin{array}{c}51.2 \\
(9.87)\end{array}$ & $\begin{array}{c}62.3 \\
(10.2)\end{array}$ & $\begin{array}{c}57.2 \\
(10.26)\end{array}$ & $\begin{array}{l}39.7 \\
(9.8)\end{array}$ & $\begin{array}{c}17.9 \\
(8.53)\end{array}$ & \\
\hline
\end{tabular}


Table A-2

Canada: non-linear least squares estimates of ETEs for clothing

\begin{tabular}{|l|c|c|c|c|c|c|c|c|}
\hline supplier & 1996 & 1997 & 1998 & 1999 & 2000 & 2001 & 2002 & 2003 \\
\hline Brazil & 43.2 & 8.8 & & & 1.7 & 1.7 & & \\
& $(2.89)$ & $(3.3)$ & & & $(3.42)$ & $(3.42)$ & & \\
China & 43.7 & 13.7 & 2.9 & & & 0.3 & & \\
& $(3.26)$ & $(3.65)$ & $(3.84)$ & & & $(3.89)$ & & \\
Dom. Rep. & 4.8 & 1.0 & & & 0.1 & & & 1.0 \\
& $(0.75)$ & $(0.76)$ & & & $(0.76)$ & & & $(0.76)$ \\
Jamaica & 40.8 & 35.7 & 60.5 & 70 & 44.4 & 9.5 & & 82.5 \\
& $(2.5)$ & $(2.75)$ & $(2.55)$ & $(2.44)$ & $(2.53)$ & $(2.4)$ & & $(2.56)$ \\
Lebanon & 128.4 & 18.9 & & 0.2 & 1.5 & & 4.4 & 42.6 \\
& $(2.6)$ & $(3.41)$ & & $(0.89)$ & $(6.61)$ & & $(2.86)$ & $(3)$ \\
Morocco & 88.3 & 69 & 96.5 & 131.6 & 139.9 & 110.6 & 69.1 & 48.4 \\
& $(2.77)$ & $(2.93)$ & $(2.73)$ & $(2.54)$ & $(2.51)$ & $(2.65)$ & $(2.9)$ & $(2.89)$ \\
Poland & 13.6 & 15.8 & 10.9 & 6 & 4.5 & 6.4 & 8.5 & 4.3 \\
& $(2.19)$ & $(2.28)$ & $(1.94)$ & $(1.34)$ & $(1.05)$ & $(1.29)$ & $(1.51)$ & $(0.96)$ \\
Korea, PR & & 82.6 & 33.3 & & 44.9 & 324.6 & 1244.3 & 890.4 \\
& & $(2.75)$ & $(3.14)$ & & $(3.19)$ & $(2.01)$ & $(1.39)$ & $(1.53)$ \\
Romania & & & & 2.9 & 9.4 & 17.6 & 22.1 & 13.8 \\
& & & & $(3.26)$ & $(3.14)$ & $(3.0)$ & $(2.88)$ & $(2.7)$ \\
Slovakia & & 2.0 & & 0.2 & 5.7 & 16.2 & 27.7 & 28.7 \\
& & $(2.48)$ & & $(0.61)$ & $(1.97)$ & $(2.12)$ & $(2.23)$ & $(2.66)$ \\
Swaziland & & 5903.4 & 129.5 & & & 8.4 & & \\
& & $(1.01)$ & $(2.57)$ & & & $(3.66)$ & & \\
Syria & 207.6 & 47.9 & 9.0 & & & 0.9 & & \\
& $(2.27)$ & $(3.12)$ & $(3.62)$ & & & $(3.77)$ & & \\
Turkey & 22.1 & 7.3 & 1.6 & & & 0.2 & & \\
& $(2.39)$ & $(2.57)$ & $(2.66)$ & & & $(2.68)$ & & \\
Uruguay & 65.4 & 19.5 & 4.0 & & & 0.4 & & \\
& $(3.22)$ & $(3.78)$ & $(4.06)$ & & & $(4.14)$ & & \\
Vietnam & 60.6 & 19 & 19.4 & 29.0 & 31.3 & 20.5 & 5.1 & \\
& $(3.02)$ & $(3.47)$ & $(3.37)$ & $(3.21)$ & $(3.17)$ & $(3.29)$ & $(3.08)$ & \\
\hline
\end{tabular}

$t$-ratios given in parentheses 
Table A-3

EU: non-linear least squares estimates of ETEs for textiles

\begin{tabular}{|c|c|c|c|c|c|c|c|c|}
\hline supplier & 1996 & 1997 & 1998 & 1999 & 2000 & 2001 & 2002 & 2003 \\
\hline Argentina & $\begin{array}{c}7.5 \\
(10.71)\end{array}$ & & $\begin{array}{c}0.6 \\
(4.69)\end{array}$ & $\begin{array}{c}3.2 \\
(7.6)\end{array}$ & $\begin{array}{c}4.3 \\
(7.91)\end{array}$ & $\begin{array}{c}2.8 \\
(7.38)\end{array}$ & $\begin{array}{c}0.1 \\
(0.96)\end{array}$ & \\
\hline Belarus & & $\begin{array}{c}4.9 \\
(9.88)\end{array}$ & $\begin{array}{c}4.1 \\
(7.48)\end{array}$ & $\begin{array}{c}4.5 \\
(7.55)\end{array}$ & $\begin{array}{c}8.9 \\
(9.42)\end{array}$ & $\begin{array}{c}16.0 \\
(10.64)\end{array}$ & $\begin{array}{c}19.4 \\
(11.86)\end{array}$ & $\begin{array}{c}7.8 \\
(15.17)\end{array}$ \\
\hline Brazil & $\begin{array}{c}5.3 \\
(6.98)\end{array}$ & $\begin{array}{c}9.9 \\
(9.4)\end{array}$ & $\begin{array}{c}8.0 \\
(9.18)\end{array}$ & $\begin{array}{c}4.8 \\
(7.8)\end{array}$ & $\begin{array}{c}3.1 \\
(6.38)\end{array}$ & $\begin{array}{c}3.4 \\
(6.87)\end{array}$ & $\begin{array}{c}3.7 \\
(7.65)\end{array}$ & $\begin{array}{c}0.2 \\
(0.72)\end{array}$ \\
\hline China & $\begin{array}{c}22.8 \\
(11.1)\end{array}$ & $\begin{array}{c}21.1 \\
(11.7)\end{array}$ & $\begin{array}{c}16.4 \\
(11.54)\end{array}$ & $\begin{array}{c}13.0 \\
(11.05)\end{array}$ & $\begin{array}{c}12.5 \\
(11.01)\end{array}$ & $\begin{array}{c}14.4 \\
(11.49)\end{array}$ & $\begin{array}{c}16.3 \\
(11.9)\end{array}$ & $\begin{array}{c}13.4 \\
(11.36)\end{array}$ \\
\hline Hong Kong & $\begin{array}{c}7.0 \\
(6.45)\end{array}$ & $\begin{array}{c}9.1 \\
(7.8)\end{array}$ & $\begin{array}{c}6.4 \\
(7.51)\end{array}$ & $\begin{array}{c}3.0 \\
(5.39)\end{array}$ & $\begin{array}{c}0.8 \\
(1.93)\end{array}$ & $\begin{array}{c}0.4 \\
(1.07)\end{array}$ & $\begin{array}{c}0.9 \\
(2.73)\end{array}$ & \\
\hline Indonesia & $\begin{array}{c}2.2 \\
(2.69)\end{array}$ & $\begin{array}{c}3.0 \\
(4.28)\end{array}$ & $\begin{array}{c}3.4 \\
(4.47)\end{array}$ & $\begin{array}{c}3.1 \\
(4.11)\end{array}$ & $\begin{array}{c}2.2 \\
(3.66)\end{array}$ & $\begin{array}{c}1.0 \\
(3.03)\end{array}$ & $\begin{array}{l}0.03 \\
(0.3)\end{array}$ & \\
\hline India & $\begin{array}{c}7.1 \\
(8.63)\end{array}$ & & $\begin{array}{c}5.5 \\
(8.23)\end{array}$ & $\begin{array}{c}2.9 \\
(6.18)\end{array}$ & $\begin{array}{c}1.6 \\
(4.11)\end{array}$ & $\begin{array}{c}1.7 \\
(4.51)\end{array}$ & $\begin{array}{c}2.1 \\
(6.22)\end{array}$ & \\
\hline South Korea & $\begin{array}{c}12.1 \\
(8.41)\end{array}$ & & $\begin{array}{c}11.4 \\
(9.03)\end{array}$ & $\begin{array}{c}10.7 \\
(8.96)\end{array}$ & $\begin{array}{c}10.3 \\
(9.19)\end{array}$ & $\begin{array}{c}9.9 \\
(9.61)\end{array}$ & $\begin{array}{c}8.6 \\
(9.59)\end{array}$ & $\begin{array}{c}4.8 \\
(6.86)\end{array}$ \\
\hline Sri Lanka & $\begin{array}{c}5.9 \\
(5.98)\end{array}$ & $\begin{array}{c}3.1 \\
(5.52)\end{array}$ & $\begin{array}{c}2.7 \\
(4.62)\end{array}$ & $\begin{array}{c}2.8 \\
(4.3)\end{array}$ & $\begin{array}{c}2.4 \\
(4.24)\end{array}$ & $\begin{array}{c}1.2 \\
(4.27)\end{array}$ & & \\
\hline Malaysia & $\begin{array}{c}10.6 \\
(7.63)\end{array}$ & & $\begin{array}{c}7.6 \\
(7.31)\end{array}$ & $\begin{array}{c}6.0 \\
(6.86)\end{array}$ & $\begin{array}{c}7.0 \\
(7.64)\end{array}$ & $\begin{array}{c}9.9 \\
(8.79)\end{array}$ & $\begin{array}{c}11.6 \\
(9.18)\end{array}$ & $\begin{array}{c}6.7 \\
(7.47)\end{array}$ \\
\hline Pakistan & $\begin{array}{c}15.1 \\
(10.3)\end{array}$ & & $\begin{array}{c}10.0 \\
(9.72)\end{array}$ & $\begin{array}{c}6.0 \\
(8.49)\end{array}$ & $\begin{array}{c}3.9 \\
(7.08)\end{array}$ & $\begin{array}{c}3.5 \\
(6.98)\end{array}$ & $\begin{array}{c}3.3 \\
(7.87)\end{array}$ & $\begin{array}{c}0.01 \\
(0.3)\end{array}$ \\
\hline Peru & $\begin{array}{c}10.2 \\
(10.21)\end{array}$ & $\begin{array}{c}3.8 \\
(6.59)\end{array}$ & $\begin{array}{c}4.3 \\
(7.38)\end{array}$ & $\begin{array}{c}6.9 \\
(9.54)\end{array}$ & $\begin{array}{c}8.7 \\
(10.42)\end{array}$ & $\begin{array}{c}8.3 \\
(10.5)\end{array}$ & $\begin{array}{c}6.1 \\
(9.87)\end{array}$ & $\begin{array}{c}4.4 \\
(8.37)\end{array}$ \\
\hline Philippines & $\begin{array}{c}0.9 \\
(1.16)\end{array}$ & $\begin{array}{c}0.2 \\
(1.17)\end{array}$ & & & $\begin{array}{c}0.04 \\
(1.17)\end{array}$ & $\begin{array}{c}0.04 \\
(1.17)\end{array}$ & & \\
\hline Korea, PR & & $\begin{array}{c}1.5 \\
(1.72)\end{array}$ & $\begin{array}{c}4.4 \\
(4.07)\end{array}$ & $\begin{array}{c}8.6 \\
(7.03)\end{array}$ & $\begin{array}{c}13.2 \\
(8.96)\end{array}$ & $\begin{array}{c}17.3 \\
(9.66)\end{array}$ & $\begin{array}{c}19.4 \\
(9.78)\end{array}$ & $\begin{array}{c}17.8 \\
(9.88)\end{array}$ \\
\hline Singapore & $\begin{array}{c}13.6 \\
(8.17)\end{array}$ & $\begin{array}{c}15.1 \\
(8.65)\end{array}$ & $\begin{array}{c}12.7 \\
(8.87)\end{array}$ & $\begin{array}{c}9.1 \\
(8.75)\end{array}$ & $\begin{array}{c}6.1 \\
(8.04)\end{array}$ & $\begin{array}{c}4.8 \\
(7.14)\end{array}$ & $\begin{array}{c}5.2 \\
(7.02)\end{array}$ & $\begin{array}{c}6.9 \\
(7.63)\end{array}$ \\
\hline Thailand & $\begin{array}{c}6.0 \\
(6.73)\end{array}$ & $\begin{array}{c}4.7 \\
(5.91)\end{array}$ & $\begin{array}{c}2.6 \\
(4.11)\end{array}$ & $\begin{array}{c}1.8 \\
(3.18)\end{array}$ & $\begin{array}{c}2.7 \\
(4.54)\end{array}$ & $\begin{array}{c}4.6 \\
(6.41)\end{array}$ & $\begin{array}{c}5.1 \\
(7.09)\end{array}$ & $\begin{array}{c}0.3 \\
(0.87)\end{array}$ \\
\hline Uzbekistan & $\begin{array}{c}12.6 \\
(12.18)\end{array}$ & $\begin{array}{c}7.9 \\
(10.43)\end{array}$ & $\begin{array}{c}6.7 \\
(9.54)\end{array}$ & $\begin{array}{c}6.0 \\
(9.37)\end{array}$ & $\begin{array}{c}4.6 \\
(9.47)\end{array}$ & $\begin{array}{c}2.2 \\
(9.68)\end{array}$ & & \\
\hline Vietnam & $\begin{array}{c}21.1 \\
(10.00)\end{array}$ & $\begin{array}{c}22.2 \\
(11.13)\end{array}$ & $\begin{array}{c}18.7 \\
(11.26)\end{array}$ & $\begin{array}{c}13.9 \\
(10.78)\end{array}$ & $\begin{array}{c}10.0 \\
(10.06)\end{array}$ & $\begin{array}{c}7.8 \\
(9.66)\end{array}$ & $\begin{array}{c}7.5 \\
(9.98)\end{array}$ & $\begin{array}{c}8.3 \\
(10.13)\end{array}$ \\
\hline
\end{tabular}

$t$-ratios given in parentheses 
Table A-4

EU: non-linear least squares estimates of ETEs for clothing

\begin{tabular}{|l|c|c|c|c|c|c|c|c|}
\hline supplier & 1996 & 1997 & 1998 & 1999 & 2000 & 2001 & 2002 & 2003 \\
\hline Brazil & 32.9 & 6.5 & & & 0.6 & & & 6.5 \\
& $(2.91)$ & $(3.25)$ & & & $(3.35)$ & & & $(3.25)$ \\
China & 94.2 & 67.8 & 41.9 & 25.1 & 18.2 & 19.3 & 24 & 24.1 \\
& $(2.72)$ & $(2.95)$ & $(3.13)$ & $(3.17)$ & $(3.15)$ & $(3.27)$ & $(3.36)$ & $(3.25)$ \\
Hong Kong & 5.6 & 1.8 & 0.3 & & 0.1 & 0.1 & & \\
& $(1.67)$ & $(1.44)$ & $(0.98)$ & & $(0.94)$ & $(1.82)$ & & \\
Indonesia & 10.1 & 3.2 & 0.5 & & 0.3 & 0.8 & 1.2 & 2.0 \\
& $(2.56)$ & $(1.75)$ & $(0.91)$ & & $(2.1)$ & $(1.0)$ & $(0.84)$ & $(1.47)$ \\
India & 23.9 & 13.5 & 6.7 & 2.7 & 0.7 & & & \\
& $(3.36)$ & $(3.2)$ & $(2.96)$ & $(2.7)$ & $(2.45)$ & & & \\
South Korea & 72.4 & 52.3 & 38.8 & 31.1 & 28 & 27.7 & 27.7 & 24.2 \\
& $(2.85)$ & $(3.03)$ & $(3.12)$ & $(3.15)$ & $(3.17)$ & $(3.19)$ & $(3.19)$ & $(3.11)$ \\
Sri Lanka & 35.6 & 18.2 & 5.6 & 0.2 & 1.7 & 8 & 14.1 & 10.3 \\
& $(2.91)$ & $(3.01)$ & $(2.77)$ & $(0.36)$ & $(1.93)$ & $(2.92)$ & $(2.98)$ & $(2.88)$ \\
Peru & 26.3 & 25.2 & 19.1 & 11.4 & 5.5 & 4.6 & 13.3 & 40.6 \\
& $(3.12)$ & $(3.34)$ & $(3.3)$ & $(2.99)$ & $(2.28)$ & $(2.15)$ & $(3)$ & $(2.94)$ \\
Philippines & 40.9 & 41.2 & 34.1 & 27.5 & 24.8 & 25.8 & 27.3 & 22.6 \\
& $(3.03)$ & $(3.11)$ & $(3.13)$ & $(3.12)$ & $(3.15)$ & $(3.24)$ & $(3.32)$ & $(3.27)$ \\
Koera, PR & 44.9 & & & 7.9 & 8.5 & 1 & & 39.5 \\
& $(2.55)$ & & & $(2.79)$ & $(2.57)$ & $(1.01)$ & & $(2.89)$ \\
Singapore & 17.6 & 1.9 & 0.6 & 3.4 & 5 & 3.3 & & \\
& $(2.82)$ & $(1.97)$ & $(0.66)$ & $(1.99)$ & $(2.36)$ & $(2.52)$ & & \\
Thailand & 48.5 & 37.2 & 26.1 & 19.2 & 16.8 & 17 & 15.6 & 6.0 \\
& $(3.02)$ & $(3.15)$ & $(3.17)$ & $(3.12)$ & $(3.13)$ & $(3.24)$ & $(3.34)$ & $(2.66)$ \\
Usbekistan & 9.6 & 80.5 & 5.7 & 0 & 17.1 & 37.8 & 37.8 & 3.7 \\
& $(2.46)$ & $(2.76)$ & $(2.86)$ & & $(3.64)$ & $(3.23)$ & $(3.12)$ & $(2.65)$ \\
Vietnam & 72.8 & 54 & 41.7 & 34 & 29.7 & 27.7 & 27.1 & 26.7 \\
& $(2.85)$ & $(3.02)$ & $(3.09)$ & $(3.11)$ & $(3.14)$ & $(3.21)$ & $(3.28)$ & $(3.22)$ \\
\hline
\end{tabular}

$t$-ratios given in parentheses 
Table A-5

USA: non-linear least squares estimates of ETEs for textiles

\begin{tabular}{|c|c|c|c|c|c|c|c|c|c|}
\hline supplier & 1996 & 1997 & 1998 & 1999 & 2000 & 2001 & 2002 & 2003 & 2004 \\
\hline Bangladesh & & $\begin{array}{c}0.3 \\
(7.53)\end{array}$ & & & $\begin{array}{c}0.8 \\
(7.52)\end{array}$ & $\begin{array}{c}2.3 \\
(7.46)\end{array}$ & $\begin{array}{c}3.7 \\
(7.41)\end{array}$ & $\begin{array}{c}3.5 \\
(7.41)\end{array}$ & \\
\hline Belarus & $\begin{array}{c}0.1 \\
(0.74)\end{array}$ & $\begin{array}{c}1.1 \\
(11.24)\end{array}$ & & & $\begin{array}{c}2.4 \\
(14.09)\end{array}$ & $\begin{array}{c}7.0 \\
(13.98)\end{array}$ & $\begin{array}{c}11.4 \\
(13.82)\end{array}$ & $\begin{array}{c}11.1 \\
(13.93)\end{array}$ & \\
\hline Brazil & $\begin{array}{c}6.6 \\
(13.56)\end{array}$ & $\begin{array}{c}10.6 \\
(13.16)\end{array}$ & $\begin{array}{c}9.7 \\
(12.91)\end{array}$ & $\begin{array}{c}6.6 \\
(12.62)\end{array}$ & $\begin{array}{c}3.3 \\
(11.99)\end{array}$ & $\begin{array}{c}1.0 \\
(10.51)\end{array}$ & & $\begin{array}{c}0.01 \\
(0.49)\end{array}$ & $\begin{array}{l}0.01 \\
(0.3)\end{array}$ \\
\hline China & $\begin{array}{c}6.9 \\
(12.10)\end{array}$ & $\begin{array}{c}4.3 \\
(10.39)\end{array}$ & $\begin{array}{c}4.6 \\
(12.39)\end{array}$ & $\begin{array}{c}5.7 \\
(14.55)\end{array}$ & $\begin{array}{c}6.3 \\
(15.57)\end{array}$ & $\begin{array}{c}6.6 \\
(16.26)\end{array}$ & $\begin{array}{c}7.8 \\
(16.67)\end{array}$ & $\begin{array}{c}12.5 \\
(15.51)\end{array}$ & $\begin{array}{c}25.3 \\
(13.23)\end{array}$ \\
\hline Colombia & $\begin{array}{c}16.9 \\
(5.51)\end{array}$ & $\begin{array}{c}4.7 \\
(5.87)\end{array}$ & $\begin{array}{c}0.05 \\
(0.36)\end{array}$ & $\begin{array}{c}0.1 \\
(0.46)\end{array}$ & $\begin{array}{c}3.4 \\
(3.67)\end{array}$ & $\begin{array}{c}8.6 \\
(4.69)\end{array}$ & $\begin{array}{c}14.5 \\
(5.31)\end{array}$ & $\begin{array}{c}19.5 \\
(6.03)\end{array}$ & $\begin{array}{c}22.3 \\
(6.89)\end{array}$ \\
\hline Czech Rep & & & $\begin{array}{c}1.0 \\
(1.98)\end{array}$ & $\begin{array}{c}2.6 \\
(2.26)\end{array}$ & $\begin{array}{c}4.7 \\
(2.77)\end{array}$ & $\begin{array}{c}7.2 \\
(3.8)\end{array}$ & $\begin{array}{c}10.7 \\
(6.03)\end{array}$ & $\begin{array}{c}15.9 \\
(10.36)\end{array}$ & $\begin{array}{c}24.0 \\
(11.83)\end{array}$ \\
\hline Hungary & & & $\begin{array}{c}3.7 \\
(6.2)\end{array}$ & $\begin{array}{c}8.1 \\
(5.95)\end{array}$ & $\begin{array}{c}11.3 \\
(5.85)\end{array}$ & $\begin{array}{c}12.9 \\
(6.14)\end{array}$ & $\begin{array}{c}14.1 \\
(7.45)\end{array}$ & $\begin{array}{c}17.5 \\
(10.91)\end{array}$ & $\begin{array}{c}28.2 \\
(12.4)\end{array}$ \\
\hline Indonesia & $\begin{array}{c}0.1 \\
(0.58)\end{array}$ & $\begin{array}{c}0.7 \\
(1.64)\end{array}$ & $\begin{array}{c}2.1 \\
(3.57)\end{array}$ & $\begin{array}{c}3.5 \\
(5.09)\end{array}$ & $\begin{array}{c}4.4 \\
(6.45)\end{array}$ & $\begin{array}{c}4.7 \\
(7.65)\end{array}$ & $\begin{array}{c}5.0 \\
(8.25)\end{array}$ & $\begin{array}{c}6.2 \\
(8.43)\end{array}$ & $\begin{array}{c}10.1 \\
(7.37)\end{array}$ \\
\hline India & $\begin{array}{c}3.9 \\
(9.95)\end{array}$ & $\begin{array}{c}4.5 \\
(11.34)\end{array}$ & $\begin{array}{c}4.0 \\
(11.08)\end{array}$ & $\begin{array}{c}3.1 \\
(9.72)\end{array}$ & $\begin{array}{c}2.1 \\
(7.51)\end{array}$ & $\begin{array}{l}1.6 \\
(5.7)\end{array}$ & $\begin{array}{c}1.8 \\
(6.16)\end{array}$ & $\begin{array}{c}3.1 \\
(9.6)\end{array}$ & $\begin{array}{c}5.8 \\
(11.57)\end{array}$ \\
\hline Jamaica & & $\begin{array}{c}0.3 \\
(1.68)\end{array}$ & & $\begin{array}{c}0.6 \\
(1.24)\end{array}$ & $\begin{array}{c}2.6 \\
(1.98)\end{array}$ & $\begin{array}{c}5.6 \\
(2.44)\end{array}$ & $\begin{array}{c}8.0 \\
(2.76)\end{array}$ & $\begin{array}{c}7.3 \\
(3.01)\end{array}$ & \\
\hline Cambodia & $\begin{array}{l}111.5 \\
(9.35)\end{array}$ & $\begin{array}{c}22.6 \\
(12.24)\end{array}$ & $\begin{array}{c}1.2 \\
(16.81)\end{array}$ & & $\begin{array}{c}4.5 \\
(12.39)\end{array}$ & $\begin{array}{c}7.0 \\
(12.36)\end{array}$ & $\begin{array}{c}4.7 \\
(12.55)\end{array}$ & & \\
\hline South Korea & & & $\begin{array}{c}0.5 \\
(2.37)\end{array}$ & $\begin{array}{c}0.9 \\
(2.22)\end{array}$ & $\begin{array}{c}0.8 \\
(1.95)\end{array}$ & $\begin{array}{c}0.3 \\
(1.37)\end{array}$ & & $\begin{array}{c}0.9 \\
(8.28)\end{array}$ & $\begin{array}{c}4.5 \\
(4.69)\end{array}$ \\
\hline Lao PDR & & $\begin{array}{c}0.4 \\
(1.27)\end{array}$ & $\begin{array}{c}3.6 \\
(9.94)\end{array}$ & $\begin{array}{c}10.6 \\
(14.07)\end{array}$ & $\begin{array}{c}20.9 \\
(12.94)\end{array}$ & $\begin{array}{c}31.5 \\
(11.94)\end{array}$ & $\begin{array}{c}36.6 \\
(11.44)\end{array}$ & $\begin{array}{c}27.8 \\
(11.63)\end{array}$ & \\
\hline Macedonia & $\begin{array}{c}102.4 \\
(10.08)\end{array}$ & $\begin{array}{c}30.2 \\
(12.34)\end{array}$ & $\begin{array}{c}6.5 \\
(13.62)\end{array}$ & & & $\begin{array}{c}1.3 \\
(13.96)\end{array}$ & $\begin{array}{c}1.3 \\
(13.96)\end{array}$ & & \\
\hline Malaysia & & & $\begin{array}{c}0.03 \\
(1.87)\end{array}$ & $\begin{array}{l}0.02 \\
(0.7)\end{array}$ & & $\begin{array}{c}0.2 \\
(2.03)\end{array}$ & $\begin{array}{c}0.8 \\
(3.43)\end{array}$ & $\begin{array}{c}2.5 \\
(4.68)\end{array}$ & $\begin{array}{c}5.8 \\
(5.68)\end{array}$ \\
\hline Pakistan & $\begin{array}{c}5.5 \\
(8.55)\end{array}$ & $\begin{array}{c}1.6 \\
(9.00)\end{array}$ & $\begin{array}{c}0.3 \\
(9.65)\end{array}$ & & $\begin{array}{c}0.03 \\
(5.92)\end{array}$ & & & $\begin{array}{c}0.6 \\
(7.54)\end{array}$ & $\begin{array}{c}2.9 \\
(7.57)\end{array}$ \\
\hline Poland & $\begin{array}{c}0.03 \\
(0.30)\end{array}$ & $\begin{array}{c}6.2 \\
(4.66)\end{array}$ & $\begin{array}{c}9.1 \\
(5.48)\end{array}$ & $\begin{array}{l}10.3 \\
(6.5)\end{array}$ & $\begin{array}{c}11.1 \\
(7.34)\end{array}$ & $\begin{array}{l}12.5 \\
(7.7)\end{array}$ & $\begin{array}{l}15.1 \\
(8.2)\end{array}$ & $\begin{array}{c}19.3 \\
(10.08)\end{array}$ & $\begin{array}{c}24.9 \\
(12.24)\end{array}$ \\
\hline Romania & $\begin{array}{c}4.9 \\
(6.85)\end{array}$ & $\begin{array}{c}2.3 \\
(4.66)\end{array}$ & $\begin{array}{c}0.3 \\
(1.69)\end{array}$ & & $\begin{array}{c}1.9 \\
(11.59)\end{array}$ & $\begin{array}{c}5.8 \\
(9.96)\end{array}$ & $\begin{array}{c}10.6 \\
(9.89)\end{array}$ & $\begin{array}{c}14.3 \\
(11.83)\end{array}$ & $\begin{array}{c}13.5 \\
(19.6)\end{array}$ \\
\hline Slovakia & $\begin{array}{c}0.1 \\
(0.62)\end{array}$ & $\begin{array}{c}14.1 \\
(7.61)\end{array}$ & $\begin{array}{c}23.0 \\
(8.62)\end{array}$ & $\begin{array}{c}26.6 \\
(9.24)\end{array}$ & $\begin{array}{c}26.4 \\
(9.23)\end{array}$ & $\begin{array}{c}24.6 \\
(8.62)\end{array}$ & $\begin{array}{c}24.4 \\
(8.22)\end{array}$ & $\begin{array}{c}29.5 \\
(9.38)\end{array}$ & $\begin{array}{c}45.3 \\
(11.54)\end{array}$ \\
\hline Thailand & & & $\begin{array}{l}0.03 \\
(2.1)\end{array}$ & $\begin{array}{l}0.03 \\
(2.1)\end{array}$ & & & $\begin{array}{l}0.1 \\
(2.1)\end{array}$ & $\begin{array}{l}0.6 \\
(2.1)\end{array}$ & $\begin{array}{c}1.6 \\
(2.09)\end{array}$ \\
\hline Turkey & & & $\begin{array}{c}0.01 \\
(1.06)\end{array}$ & $\begin{array}{c}0.01 \\
(1.06)\end{array}$ & & & $\begin{array}{c}0.05 \\
(1.06)\end{array}$ & $\begin{array}{c}0.2 \\
(1.06)\end{array}$ & $\begin{array}{c}0.5 \\
(1.06)\end{array}$ \\
\hline Ukraine & & & & $\begin{array}{c}0.7 \\
(6.63)\end{array}$ & $\begin{array}{c}3.0 \\
(7.81)\end{array}$ & $\begin{array}{c}7.7 \\
(9.12)\end{array}$ & $\begin{array}{c}16.2 \\
(10.3)\end{array}$ & $\begin{array}{c}30.5 \\
(10.72)\end{array}$ & $\begin{array}{c}54.0 \\
(9.86)\end{array}$ \\
\hline Uruguay & & & $\begin{array}{c}2.2 \\
(4.99)\end{array}$ & $\begin{array}{c}4.3 \\
(4.58)\end{array}$ & $\begin{array}{c}5.2 \\
(4.22)\end{array}$ & $\begin{array}{c}5.5 \\
(4.28)\end{array}$ & $\begin{array}{c}7.5 \\
(5.63)\end{array}$ & $\begin{array}{c}15.2 \\
(8.09)\end{array}$ & $\begin{array}{c}36.8 \\
(8.72)\end{array}$ \\
\hline Vietnam & $\begin{array}{c}78.9 \\
(10.19)\end{array}$ & $\begin{array}{l}101.3 \\
(9.89)\end{array}$ & $\begin{array}{c}95.7 \\
(9.92)\end{array}$ & $\begin{array}{c}73.5 \\
(10.25)\end{array}$ & $\begin{array}{c}47.1 \\
(10.74)\end{array}$ & $\begin{array}{c}24.3 \\
(11.22)\end{array}$ & & & \\
\hline
\end{tabular}

$t$-ratios given in parentheses 
Table A-6

USA: non-linear least squares estimates of ETEs for clothing

\begin{tabular}{|c|c|c|c|c|c|c|c|c|c|}
\hline supplier & 1996 & 1997 & 1998 & 1999 & 2000 & 2001 & 2002 & 2003 & 2004 \\
\hline Bulgaria & & & $\begin{array}{c}0.4 \\
(1.52)\end{array}$ & $\begin{array}{c}0.3 \\
(1.19)\end{array}$ & $\begin{array}{c}0.0622 \\
(0.52)\end{array}$ & $\begin{array}{c}0.7 \\
(0.83)\end{array}$ & $\begin{array}{c}4.3 \\
(2.13)\end{array}$ & $\begin{array}{l}14.6 \\
(3.24)\end{array}$ & $\begin{array}{c}39 \\
(3.49)\end{array}$ \\
\hline Brazil & $\begin{array}{c}3.5 \\
(2.43)\end{array}$ & $\begin{array}{c}0.1 \\
(0.6)\end{array}$ & & $\begin{array}{c}0.6 \\
(5.05)\end{array}$ & $\begin{array}{c}0.6 \\
(4.67)\end{array}$ & & & $\begin{array}{c}3.0 \\
(4.22)\end{array}$ & $\begin{array}{c}13.2 \\
(3.97)\end{array}$ \\
\hline China & $\begin{array}{c}76.4 \\
(2.99)\end{array}$ & $\begin{array}{c}73.5 \\
(3)\end{array}$ & $\begin{array}{c}58.7 \\
(3.13)\end{array}$ & $\begin{array}{c}46.1 \\
(3.26)\end{array}$ & $\begin{array}{l}42.2 \\
(3.3)\end{array}$ & $\begin{array}{c}49.2 \\
(3.22)\end{array}$ & $\begin{array}{c}67.2 \\
(3.04)\end{array}$ & $\begin{array}{c}92.6 \\
(2.85)\end{array}$ & $\begin{array}{l}112.8 \\
(2.74)\end{array}$ \\
\hline Colombia & $\begin{array}{c}0.9 \\
(0.71)\end{array}$ & & & $\begin{array}{c}0.2 \\
(0.71)\end{array}$ & $\begin{array}{c}0.2 \\
(0.71)\end{array}$ & & & $\begin{array}{c}0.9 \\
(0.71)\end{array}$ & $\begin{array}{c}3.7 \\
(0.7)\end{array}$ \\
\hline Czech Rep & $\begin{array}{c}15.7 \\
(2.18)\end{array}$ & $\begin{array}{c}44.6 \\
(2.75)\end{array}$ & $\begin{array}{l}61.8 \\
(2.8)\end{array}$ & $\begin{array}{c}74.4 \\
(2.79)\end{array}$ & $\begin{array}{c}91.7 \\
(2.73)\end{array}$ & $\begin{array}{l}122.4 \\
(2.59)\end{array}$ & $\begin{array}{c}177 \\
(2.38)\end{array}$ & $\begin{array}{l}269.1 \\
(2.14)\end{array}$ & $\begin{array}{l}414.3 \\
(1.87)\end{array}$ \\
\hline Hungary & 0 & $\begin{array}{c}0.4 \\
(0.59)\end{array}$ & $\begin{array}{c}8.8 \\
(2.78)\end{array}$ & $\begin{array}{c}21.5 \\
(2.74)\end{array}$ & $\begin{array}{c}35.6 \\
(2.69)\end{array}$ & $\begin{array}{l}49.1 \\
(2.7)\end{array}$ & $\begin{array}{c}61.7 \\
(2.78)\end{array}$ & $\begin{array}{c}76 \\
(2.88)\end{array}$ & $\begin{array}{c}99.7 \\
(2.83)\end{array}$ \\
\hline India & $\begin{array}{c}19.9 \\
(3.72)\end{array}$ & $\begin{array}{c}9.3 \\
(3.31)\end{array}$ & $\begin{array}{c}3.2 \\
(2.74)\end{array}$ & $\begin{array}{c}0.4 \\
(1.39)\end{array}$ & & $\begin{array}{c}1.7 \\
(2.78)\end{array}$ & $\begin{array}{c}5.4 \\
(2.97)\end{array}$ & $\begin{array}{c}11.5 \\
(3.29)\end{array}$ & $\begin{array}{c}20.5 \\
(3.69)\end{array}$ \\
\hline Cambodia & $\begin{array}{c}60.6 \\
(3.17)\end{array}$ & $\begin{array}{c}19.2 \\
(3.67)\end{array}$ & $\begin{array}{c}4.3 \\
(3.93)\end{array}$ & & & $\begin{array}{l}0.8 \\
(4)\end{array}$ & $\begin{array}{l}0.8 \\
(4)\end{array}$ & & \\
\hline Lao PDR & & $\begin{array}{c}8.8 \\
(2.6)\end{array}$ & $\begin{array}{l}12.5 \\
(2.64)\end{array}$ & $\begin{array}{c}36.6 \\
(2.87)\end{array}$ & $\begin{array}{l}107.2 \\
(2.52)\end{array}$ & $\begin{array}{l}257.1 \\
(2.05)\end{array}$ & $\begin{array}{l}428.1 \\
(1.79)\end{array}$ & $\begin{array}{l}315.6 \\
(1.95)\end{array}$ & \\
\hline Poland & $\begin{array}{c}26.9 \\
(2.69)\end{array}$ & $\begin{array}{c}86.7 \\
(2.72)\end{array}$ & $\begin{array}{l}111.8 \\
(2.58)\end{array}$ & $\begin{array}{l}117.7 \\
(2.53)\end{array}$ & $\begin{array}{l}124.4 \\
(2.47)\end{array}$ & $\begin{array}{l}140.4 \\
(2.41)\end{array}$ & $\begin{array}{l}159.6 \\
(2.37)\end{array}$ & $\begin{array}{l}155.9 \\
(2.45)\end{array}$ & $\begin{array}{c}95.8 \\
(2.81)\end{array}$ \\
\hline Korea, PR. & & & & & & & & $\begin{array}{c}1537.2 \\
(1.33)\end{array}$ & $\begin{array}{c}1284.4 \\
(1.24)\end{array}$ \\
\hline Romania & $\begin{array}{c}3.7 \\
(1.8)\end{array}$ & $\begin{array}{c}4.1 \\
(1.86)\end{array}$ & $\begin{array}{c}13.2 \\
(3.23)\end{array}$ & $\begin{array}{l}28.7 \\
(3.2)\end{array}$ & $\begin{array}{c}49.3 \\
(2.99)\end{array}$ & $\begin{array}{c}73.9 \\
(2.81)\end{array}$ & $\begin{array}{l}101.6 \\
(2.66)\end{array}$ & $\begin{array}{c}133 \\
(2.55)\end{array}$ & $\begin{array}{l}171.4 \\
(2.42)\end{array}$ \\
\hline Slovakia & & & & $\begin{array}{c}5.9 \\
(3.03)\end{array}$ & $\begin{array}{c}21.6 \\
(2.87)\end{array}$ & $\begin{array}{c}50 \\
(2.65)\end{array}$ & $\begin{array}{c}90.10001 \\
(2.47)\end{array}$ & $\begin{array}{l}126.7 \\
(2.45)\end{array}$ & $\begin{array}{c}125 \\
(2.67)\end{array}$ \\
\hline Turkey & & $\begin{array}{c}1.2 \\
(1.02)\end{array}$ & $\begin{array}{c}0.3 \\
(0.7)\end{array}$ & & $\begin{array}{l}1.8 \\
(1.7)\end{array}$ & $\begin{array}{c}6.2 \\
(1.72)\end{array}$ & $\begin{array}{c}12.8 \\
(1.89)\end{array}$ & $\begin{array}{c}19.6 \\
(2.45)\end{array}$ & $\begin{array}{c}22.7 \\
(3.95)\end{array}$ \\
\hline Uruguay & $\begin{array}{l}102.7 \\
(2.73)\end{array}$ & $\begin{array}{l}172.7 \\
(2.42)\end{array}$ & $\begin{array}{l}129.1 \\
(2.61)\end{array}$ & $\begin{array}{c}74.2 \\
(2.91)\end{array}$ & $\begin{array}{c}48.6 \\
(3.03)\end{array}$ & $\begin{array}{c}51.3 \\
(2.91)\end{array}$ & $\begin{array}{c}69.8 \\
(2.77)\end{array}$ & $\begin{array}{c}67.1 \\
(2.82)\end{array}$ & \\
\hline Vietnam & $\begin{array}{l}471.2 \\
(1.82)\end{array}$ & $\begin{array}{l}432.7 \\
(1.85)\end{array}$ & $\begin{array}{l}555.9 \\
(1.72)\end{array}$ & $\begin{array}{l}630.3 \\
(1.65)\end{array}$ & $\begin{array}{l}496.5 \\
(1.76)\end{array}$ & $\begin{array}{l}250.4 \\
(2.13)\end{array}$ & $\begin{array}{c}74.5 \\
(2.85)\end{array}$ & & \\
\hline
\end{tabular}

$t$-ratios given in parentheses 